\title{
Comparison of two time-variant forced eddy-permitting global ocean circulation models with hydrography of the Scotia Sea
}

\author{
Sally E. Thorpe ${ }^{\mathrm{a}, \mathrm{b}, *}$, David P. Stevens ${ }^{\mathrm{c}}$, Karen J. Heywood ${ }^{\mathrm{a}}$ \\ a School of Environmental Sciences, University of East Anglia, Norwich NR4 7TJ, UK \\ ${ }^{\mathrm{b}}$ British Antarctic Survey, Natural Environment Research Council, High Cross, Madingley Road, \\ Cambridge CB3 OET, UK \\ ${ }^{c}$ School of Mathematics, University of East Anglia, Norwich NR4 7TJ, UK
}

Received 6 April 2004; received in revised form 7 April 2004; accepted 16 April 2004

Available online 8 May 2004

\begin{abstract}
A comparison between hydrographic observations and output from two realistically forced $z$-level global ocean circulation models (OCCAM and POCM_4C) in the Scotia Sea, South Atlantic, is described. The study region includes the southern part of the Antarctic Circumpolar Current (ACC) and the northern Weddell Gyre. Despite similar formulations, the models have different strengths and weaknesses. OCCAM simulates well the horizontal circulation around South Georgia but loss of Antarctic Bottom Water distorts the mean circulation in the central Scotia Sea. A poorer bathymetric dataset in POCM_4C means that the circulation is not adequately topographically steered leading to greater zonal flow and a southward shift of the fronts of the southern ACC. In a comparison with sea surface height variability data, OCCAM overestimates and POCM_4C underestimates the maximum values. Both models have higher background variability than the satellite data. Mean monthly model output is compared with a meridional hydrographic section from the study region. The regional water masses at the time of the hydrographic section (April 1995) are recognisably reproduced in both models despite some discrepancies. The surface waters are too saline in OCCAM (by 0.12-0.40) and too warm in POCM_4C (by $>2{ }^{\circ} \mathrm{C}$ ) suggesting problems with the airsea surface heat and freshwater fluxes used to force both models and the models' vertical mixing parameterisations. Anomalous mixed layer properties in winter lead to inaccurate Winter Water characteristics in both models. Slumping of Circumpolar Deep Water occurs in OCCAM, associated with the loss of the bottom water. Subsurface restoration to climatology at buffer zones prevents this slumping in POCM_4C
\end{abstract}

\footnotetext{
${ }^{*}$ Corresponding author. Address: British Antarctic Survey, Natural Environment Research Council, High Cross, Madingley Road, Cambridge CB3 0ET, UK. Tel.: +44-1223221598; fax: +44-1223221259.

E-mail address: seth@bas.ac.uk (S.E. Thorpe).
} 
although the densest waters are not reproduced. The models overestimate the baroclinic transport of the section by up to a factor of two and simulate a significant barotropic component of transport. Overall, both models can be used in this region in ways that utilise their strengths. Further improvements are likely to come from better bathymetric representations, surface fluxes, and bottom water formation processes, elimination of spurious diapycnal mixing, improvement of vertical mixing parameterisations, and higher resolution.

(C) 2004 Elsevier Ltd. All rights reserved.

Keywords: Numerical ocean model; High resolution; Hydrography; OCCAM; POCM; South Atlantic; Southern Ocean; Scotia Sea $\left[50-65^{\circ} \mathrm{S}, 65-30^{\circ} \mathrm{W}\right]$

\section{Introduction}

Validating ocean models is an important procedure, not only for identifying the strengths and weaknesses of particular models, but also for their continuing development and improvement. One of the aims of the World Ocean Circulation Experiment (WOCE) was 'to collect a global dataset for validating and improving ocean circulation models'. Accordingly, here we present a regional comparison of WOCE data and model output. We examine output from two models, the Ocean Circulation and Climate Advanced Modelling Project (OCCAM) model and the Parallel Ocean Climate Model (POCM), and compare it with historical horizontal circulation fields, altimetric sea surface height variability data and aWOCE hydrographic section from the Scotia Sea/ Weddell Gyre, South Atlantic. Both models are $z$-level models of the Bryan-Cox-Semtner type forced with time-varying fluxes but some differences in their formulations lead to large differences in their simulations of the regional water masses and circulation.

The Scotia Sea is a relatively small basin in the Southwest Atlantic sector of the Southern Ocean. It is bounded by rugged bathymetry to the north, south and east and is open to Drake Passage in the west (Fig. 1(a) and (b)). The central region of the basin is generally deeper than $3000 \mathrm{~m}$ with relatively few topographic features whereas the eastern part of the basin has more complex bathymetry. The island of South Georgia lies at the eastern end of the North Scotia Ridge with a deep passage to its east that permits exchange between the Scotia Basin and the Georgia Basin to its north. Deep passages through the South Scotia Ridge allow bottom waters to spill over from the Weddell Sea into the Scotia Sea.

The circulation of the Scotia Sea is dominated by the Antarctic Circumpolar Current (ACC). The ACC is topographically steered; it follows a predominantly northeastward course through the Scotia Sea but the southern part is steered northwards at approximately $30^{\circ} \mathrm{W}$ by the South Sandwich Island Arc (situated just east of the study region at about $27^{\circ} \mathrm{W}$ ). The ACC comprises several fast flowing, bottom reaching current cores associated with thermohaline fronts with slower moving water in between. From north to south these fronts are: the Subtropical Front, Subantarctic Front, Polar Front and southern ACC front (e.g., Whitworth and Nowlin, 1987; Orsi et al., 1995) (Fig. 1(a)). The southern boundary of the ACC (also referred to as the Scotia Front in earlier literature) is a distinct feature marking the southern limit of the water masses of the ACC. This too may have an associated current jet (e.g., Rintoul and Bullister, 1999; Heywood and King, 2002). 


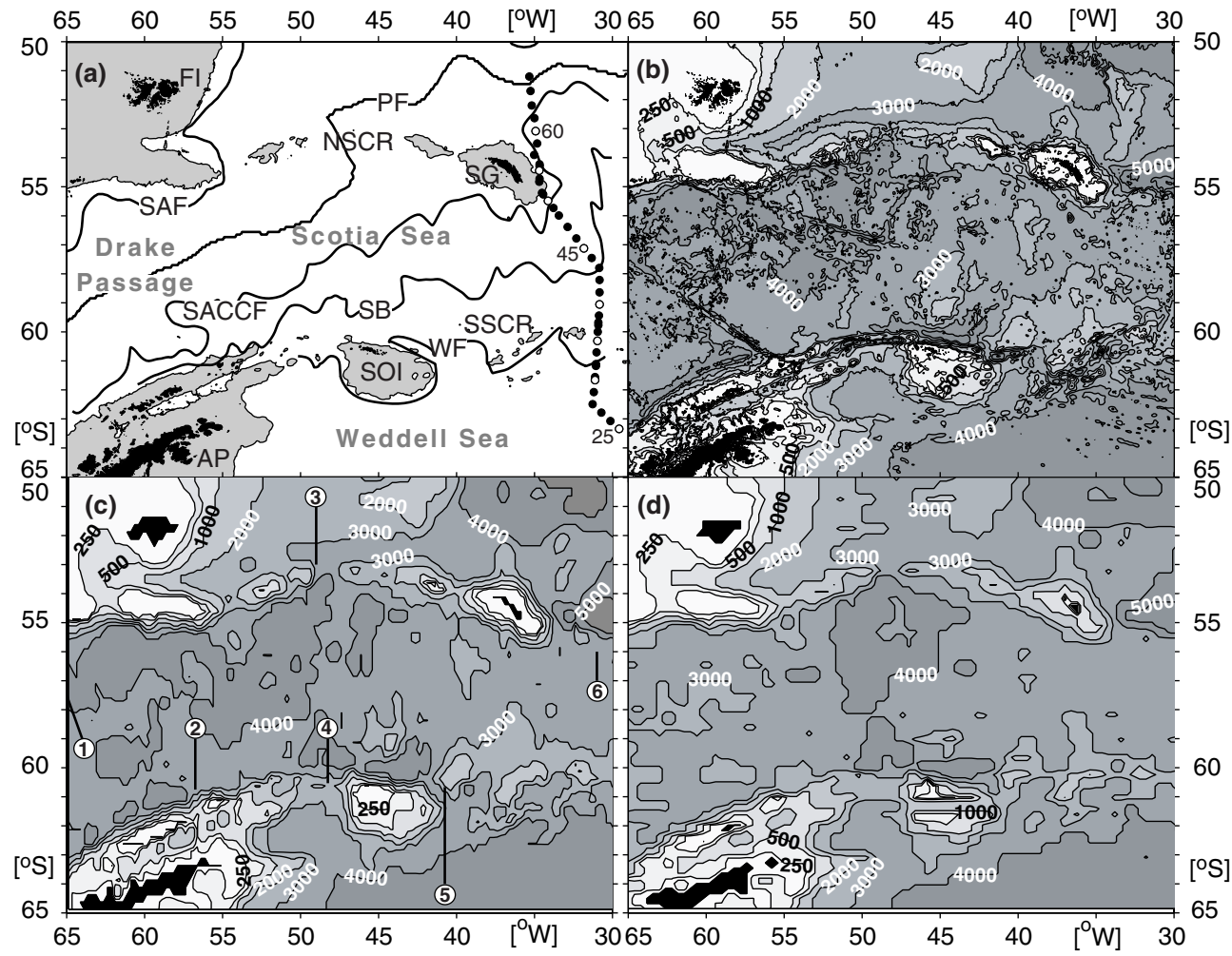

Fig. 1. (a) Map of the study region. Bathymetry shallower than $1000 \mathrm{~m}$ is shaded grey, land is black (from the Smith and Sandwell (1997) dataset). Thick solid lines indicate the mean position of the Subantarctic Front (SAF), the Polar Front (PF), the southern ACC front (SACCF), the southern boundary of the ACC (SB) and the Weddell Front (WF) (after Orsi et al., 1995; Moore et al., 1997; Thorpe, 2001; Heywood et al., in press). The A23 subsection stations are marked (circles), every fifth station starting with station 25 at the southern end of the transect is filled white. Land masses marked are: AP — Antarctic Peninsula, FI-Falkland Islands, SG-South Georgia, SOI-South Orkney Islands. NSCR and SSCR mark the North and South Scotia Ridges respectively. (b) Detailed bathymetry of the study region from Smith and Sandwell (1997). Isobaths of 250, 500, 1000, 2000, 3000, 4000 and $5000 \mathrm{~m}$ are marked. Shading gets darker with depth. (c) As (b) but for the OCCAM bathymetry. Numbers refer to locations where the model depths were verified: 1-Drake Passage; 2-Shackleton Fracture Zone; 3-Shag Rocks Passage; 4 -Powell Basin; 5 - Orkney Passage; 6-Georgia Passage (Webb et al., 1998; Thompson, 1995). (d) As (b) but for the POCM_4C bathymetry.

To the south of the ACC is the Weddell-Scotia Confluence, a zone of eastward flowing water that separates waters of the ACC from waters of the Weddell Sea. It has its source at the Antarctic Peninsula and comprises a mixture of waters from the ACC and Weddell Sea with water from the shelf of the northwest Weddell Sea (Whitworth et al., 1994). The Weddell Front forms the boundary between the Weddell-Scotia Confluence and the waters of the Weddell Sea to the south (Gordon et al., 1977). It is associated with part of the cyclonic flow of the Weddell Gyre. Observations of the Weddell Front at several crossings along the South Scotia Ridge indicate a transport of 5-7 Sv, of which most is barotropic (Heywood et al., in press).

The physical oceanography of the Scotia Sea makes a good test for the models. The topographically-steered ACC is dynamically unstable and inclusion of the Weddell-Scotia Confluence 
and the Weddell Gyre adds to the difficulty of the test. The Scotia Sea is an area of intense water mass modification (Whitworth and Nowlin, 1987; Locarnini et al., 1993; Naveira Garabato et al., 2002) and provides a pathway for the recently ventilated deep waters formed in the Weddell Sea to enter the South Atlantic and join the global circulation (e.g., Locarnini et al., 1993; Naveira Garabato et al., 2002). Ecologically, the region is of great importance; South Georgia supports large breeding colonies of seabirds and seals (e.g., Croxall, 1987). Numerical ocean models are being used more frequently to investigate the impacts of physical variability on the South Georgia ecosystem (e.g., Murphy et al., 1998; Thorpe et al., 2002).

Earlier studies have shown that $z$-level models have difficulty retaining their densest water masses after long integration periods (Chassignet et al., 1996). In $z$-level models dense over-flows mix vigorously with the surrounding waters as they cross the North Atlantic ridges with the result that their properties are changed relatively quickly (Gerdes, 1993; Roberts et al., 1996). The ridges bounding the Scotia Sea may cause such problems in our study area. Application of relaxation towards observed temperature and salinity properties in buffer zones at a model's boundaries should keep a certain amount of high density water everywhere in the model's domain as it is advected away from the boundaries (Chassignet et al., 1996). Of the two models that we are examining, only POCM applies subsurface restoration at buffer zones. In our study, we look at how effective this is at retaining dense bottom waters in the model compared with OCCAM. Lee et al. (2002) found that the deep and bottom waters of OCCAM in the Southern Ocean drift rapidly away from climatology, due to excessive spurious diapycnal mixing. Isopycnal models, in which potential density is used as the vertical coordinate, do not suffer from this problem since, due to transport in these models occurring along isopycnic surfaces by construction, the numerical diffusion has no diapycnal component. No high resolution isopycnal models of our study region are currently available for comparison.

The paper continues with a description of the two models. Horizontal circulation at three levels (near-surface, 1000-2000 $\mathrm{m}$ and near-bottom) and sea surface height variability are examined in Section 3. In Section 4 the water mass characteristics and fronts observed in the WOCE hydrographic section are compared with those of the models. A discussion of the results is presented in Section 5 and the paper concludes with a summary of the main findings in Section 6.

\section{The models}

Output from time-varying forced runs of OCCAM and POCM (version POCM_4C) are used in this study. The basic configurations of OCCAM and POCM_4C are similar: both are eddy permitting, $z$-level primitive equation models of the Bryan-Cox-Semtner type, include a free surface (Killworth et al., 1991) and have similar lateral resolutions (approximately $\frac{1}{4}^{\circ} \times \frac{1}{4}^{\circ}$ ). OCCAM has been integrated for the period 1992-2000 with six hourly reanalysed wind forcing (Lee et al., 2002; Webb and de Cuevas, 2003). POCM_4C was run for a 20 year period (19791998) with daily forcing of winds, heat and freshwater (Tokmakian and Challenor, 1999). Further details of the configuration of the two models are given in Table 1. Neither model employs a dynamic sea-ice model, nor are the surface fluxes modified based on climatological ice distributions. 
Table 1

Details of the OCCAM and POCM_4C model runs used in this study

\begin{tabular}{|c|c|c|}
\hline Parameter & OCCAM & POCM_4C \\
\hline Domain & Global & $75^{\circ} \mathrm{S}-65^{\circ} \mathrm{N}$ \\
\hline Horizontal resolution & $0.25^{\circ} \times 0.25^{\circ}$ & $\begin{array}{l}0.4 \cos (\phi)^{\circ} \times 0.4^{\circ} \text { longitude: average } \\
0.25^{\circ}\end{array}$ \\
\hline Vertical levels & 36 & 20 \\
\hline Layer thickness & $20.0-255.59 \mathrm{~m}$ & $25.0-550.0 \mathrm{~m}$ \\
\hline Simulation period & $1992-2000$ & 1979-1998 \\
\hline Sampling period & 5 days & 3 days \\
\hline Bathymetry & DBDB5 (US Navy, 1983) & ETOPO5 (NGDC, 1988) \\
\hline Wind forcing & 6 hourly, ECMWF & Daily, ECMWF \\
\hline Salinity/freshwater forcing & $\begin{array}{l}\text { Restoration to mean monthly } S \\
\text { (Levitus et al., 1994; } \gamma=30 \text { days) }\end{array}$ & $\begin{array}{l}\text { Daily, ECMWF, with surface resto- } \\
\text { ration to mean monthly } S \text { [Levitus } \\
\text { et al. (1994), } \gamma=90 \text { days] }\end{array}$ \\
\hline Heat flux & $\begin{array}{l}\text { As salinity, but Levitus and Boyer } \\
\text { (1994) } T\end{array}$ & $\begin{array}{l}\text { As freshwater, but Levitus and Boyer } \\
\text { (1994) } T\end{array}$ \\
\hline Subsurface restoration & None & $\begin{array}{l}\text { Upper } 2000 \mathrm{~m} \text { at } 58-65^{\circ} \mathrm{N} \\
68-75^{\circ} \mathrm{S} \text { and Strait of Gibraltar }\end{array}$ \\
\hline Horizontal diffusion & $\begin{array}{l}\text { Laplacian mixing, coefficient of } \\
1 \times 10^{6} \mathrm{~cm}^{2} \mathrm{~s}^{-1}\end{array}$ & $\begin{array}{l}\text { Biharmonic mixing, coefficient of } \\
-5 \times 10^{19} \cos ^{2.25} \phi \mathrm{cm}^{4} \mathrm{~s}^{-1}\end{array}$ \\
\hline Horizontal viscosity & $\begin{array}{l}\text { Laplacian mixing, coefficient of } \\
2 \times 10^{6} \mathrm{~cm}^{2} \mathrm{~s}^{-1}\end{array}$ & $\begin{array}{l}\text { Biharmonic mixing, coefficient of } \\
-1.1 \times 10^{20} \cos ^{2.25} \phi \mathrm{cm}^{4} \mathrm{~s}^{-1}\end{array}$ \\
\hline Vertical diffusion and viscosity & Pacanowski and Philander (1981) & Pacanowski and Philander (1981) \\
\hline \multirow[t]{4}{*}{ References } & Webb et al. (1998) & Semtner and Chervin (1992) \\
\hline & Saunders et al. (1999) & Stammer et al. (1996) \\
\hline & Lee et al. (2002) & McClean et al. (1997) \\
\hline & Webb and de Cuevas (2003) & Tokmakian and Challenor (1999) \\
\hline
\end{tabular}

$\phi$ is latitude, $S$ salinity, $T$ temperature and $\gamma$ restoration timescale. NGDC-National Geophysical Data Center, ECMWF-European Centre for Medium-Range Weather Forecasting. ECMWF fields used in both models are reanalysis for 1979-1993, operational for 1994 onwards.

The initial climatologically forced run of OCCAM was started from rest with temperature and salinity fields initialised from the Levitus (1982) global annual average dataset (Webb et al., 1998; Lee et al., 2002). During the first four years of the integration, the tracer fields were relaxed towards climatological data (Levitus (1982) data for the first 180 days of the model run, Levitus and Boyer (1994) and Levitus et al. (1994) data thereafter). Mean monthly data were used at the surface with a relaxation timescale of 30 days while mean annual data were used at all other levels with a 360 day timescale. For the following four years, the subsurface relaxation was turned off. The surface wind forcing was increased from zero at the start of the run to full strength over two months, using mean monthly fields interpolated from the Siefridt and Barnier (1993) wind stress climatology for 1986-1988. The six hourly wind forced run of OCCAM used in this study was started from near the end of the eight year climatological integration. For this run, the wind forcing was switched to six hourly reanalysed winds from the European Centre for Medium-range Weather Forecasting (ECMWF) for the period 1992 onwards. The surface fluxes of heat and fresh water are calculated so that the surface layer of the model relaxes to the mean monthly Levitus and Boyer (1994) and Levitus et al. (1994) values with a timescale of 30 days as in the earlier run. 
This is to avoid possible errors in the ECMWF surface flux fields, particularly in the Southern Ocean where there are few observational data (de Cuevas and Webb, 1999).

POCM_4C is an evolution of the $\frac{1}{2}^{\circ} \times \frac{1}{2}^{\circ}$ Semtner and Chervin model (Semtner and Chervin, 1992). The lower resolution model was initialised from Levitus (1982) temperature and salinity and integrated for a 32.5 year period. Temperature and salinity were forced to annual mean Levitus (1982) data for the first 22.5 years and seasonal data thereafter, with annual mean and monthly mean wind stress fields (Hellerman and Rosenstein, 1983) respectively. At the end of that run, the instantaneous fields were interpolated onto the higher resolution, average $\frac{1}{4}^{\circ} \times \frac{1}{4}^{\circ}$ grid and a free surface was incorporated. The model run resumed for the period 1986-1989 with monthly mean wind stress fields and restoration of surface temperature and salinity towards monthly mean Levitus (1982) climatology (model version POCM_4A). POCM_4B was started from a model state at the end of POCM_4A and was integrated for the 10 year period 1987-1996 with daily ECMWF wind stress fields and monthly mean sea surface heat fluxes (Barnier et al., 1995), with more recent mean monthly data (Levitus and Boyer, 1994; Levitus et al., 1994) used for surface restoration of temperature and salinity with a timescale of 30 days (Stammer et al., 1996). Both POCM_4A and POCM_4B employed subsurface restoration of temperature and salinity fields in the region of the northern and southern boundaries of the model domain over the upper $2000 \mathrm{~m}$ to imitate the exchange of water mass properties with areas outside the model domain. Further detailed information on these earlier runs is given by Stammer et al. (1996). POCM_4C, the version that we use here, was initialised from POCM_4B and differs in that it applies daily varying surface fluxes of momentum, heat and freshwater (Tokmakian and Challenor, 1999; Table 1). Surface temperature and salinity are restored to mean monthly Levitus and Boyer (1994) and Levitus et al. (1994) data with a 90 day timescale and imbalances in the heat and freshwater fluxes are corrected so that the annual mean global imbalance is zero. The surface restoration terms are applied to regulate the surface fluxes and should limit drift of the model from the climatological data. Subsurface restoration of temperature and salinity over the upper $2000 \mathrm{~m}$ of the water column is also employed in POCM_4C in the region of the northern and southern boundaries and the Strait of Gibraltar (Table 1). In these regions, the model values are relaxed to mean monthly data (Levitus and Boyer, 1994; Levitus et al., 1994) with a 90 day timescale. This process, not employed in OCCAM which is truly global, ensures that the properties of the water masses in the upper $2000 \mathrm{~m}$ of the water column are continuously regulated and that deep water masses are formed, albeit artificially, in POCM_4C.

The topographically steered nature of the ACC means that, to simulate well the oceanic flow in this region, the models' representation of bathymetry should be realistic. The bathymetries of the two models are based on different $\frac{1}{12}^{\circ}$ topographic datasets (Table 1) and were created using slightly different methods: OCCAM by taking the median value from each grid cell followed by manual checking and correction, if necessary, of the key sills and channels (Webb et al., 1998) using the list of the depths produced by Thompson (1995); POCM_4C by averaging the depth values in each grid cell (Stammer et al., 1996). This has resulted in noticeable differences between the two bathymetric datasets in the Scotia Sea (Fig. 1(c) and (d)). Of the two models, the bathymetry used in OCCAM is the most realistic (Fig. 1(c)). It reproduces the main features from the Smith and Sandwell (1997) dataset (Fig. 1(b)) accurately and South Georgia and its shelf are well resolved. POCM_4C has fewer vertical levels than OCCAM and so the bathymetry is unlikely to be as well resolved. In fact, the POCM_4C bathymetry (Fig. 1(d)) is clearly wrong in several 
places: there are passages through the Falkland and South Orkney Plateaux, seen in neither the Smith and Sandwell (1997) nor the GEBCO (General Bathymetric Chart of the Oceans) datasets nor in OCCAM, and the Drake Passage region is much shallower in POCM_4C. The Orkney Passage (marked in Fig. 1(c)), although realistic in OCCAM due to the manual checking, is not well resolved in POCM_4C and the area of the South Georgia shelf is much reduced. The Falkland and South Orkney Plateaux are not areas included in the manual checking performed on the OCCAM bathymetry (Fig. 1(c)). This suggests that either the method for creating the POCM_4C bathymetry was not as effective as that used for OCCAM or that there are discrepancies between the ETOPO5 dataset from which the POCM_4C bathymetry was derived and DBDB5 from which the OCCAM bathymetry was derived.

The two models employ the same vertical mixing schemes but different horizontal mixing schemes (Table 1). The horizontal mixing in OCCAM is Laplacian with constant coefficient. Horizontal mixing in POCM_4C is biharmonic and scaled by latitude to reduce mixing at high latitudes (Stammer et al., 1996). The biharmonic mixing is scale selective and preferentially damps high wave numbers.

Temporal mean output fields from the models are used in this work to eliminate aliasing of inertial oscillations that occurs when forcing models with high frequency wind stress and sampling the output as snapshots (Jayne and Tokmakian, 1997). A monthly mean from April 1995 will be used primarily, chosen to coincide with the occupation of the WOCE hydrographic section discussed.

\section{Horizontal circulation of the Scotia Sea}

\subsection{Near surface circulation}

A climatological geopotential anomaly field calculated from historical hydrographic data for the study region (Fig. 2(a)) is compared with model output to examine the near-surface circulation of the Scotia Sea region in the models. All CTD and bottle temperature and salinity data were extracted for the region $50-65^{\circ} \mathrm{S}, 65-30^{\circ} \mathrm{W}$ from the World Ocean Database 1998 (thereby incorporating more recent data than the geopotential anomaly maps of Gordon et al. (1978), Olbers et al. (1992) and Orsi et al. (1995)), compiled by the Ocean Climate Laboratory of the National Oceanographic Data Center (Levitus et al., 1998) (Fig. 2(b)). An additional station was incorporated that was missing from the database in its full depth form (station $281\left(52.273^{\circ} \mathrm{S}\right.$, $41.747^{\circ} \mathrm{W}$ ) from the RS Melville South Atlantic Ventilation Experiment cruise in 1989). Following quality control to remove duplicate stations and any spikes in the data, geopotential anomaly was calculated. The geopotential anomaly field (gridded on $\frac{1}{4}^{\circ} \times \frac{1}{4}^{\circ}$ resolution) uses $50 \mathrm{db}$ as the upper reference level to remove any variability in the data introduced from the seasonality of the measurements, following Orsi et al. (1995). $1000 \mathrm{db}$ is chosen for the lower reference level because many of the available historical data do not have measurements deeper than this. Gordon et al. (1978) show that using a reference level of $1000 \mathrm{db}$ gives a meaningful picture of surface geostrophic flow in the Southern Ocean as compared with a reference level of $3000 \mathrm{db}$.

Corresponding mean geopotential anomaly fields have been calculated from the 5 day mean potential temperature and salinity fields from OCCAM for the period 1993-1995 (constrained by 


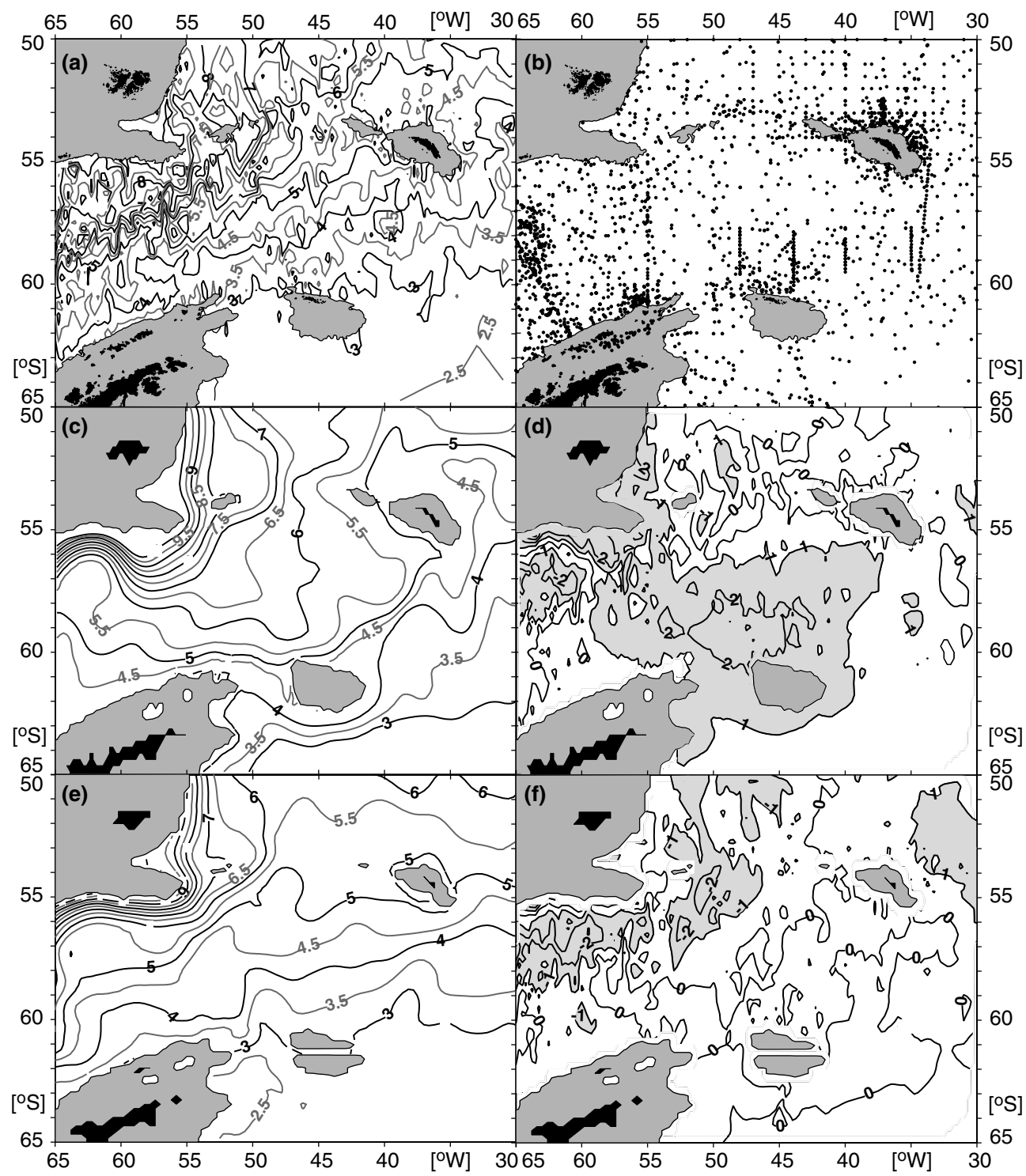

Fig. 2. (a) Mean geopotential anomaly (at $50 \mathrm{db}$ relative to $1000 \mathrm{db}, \mathrm{J} \mathrm{kg}^{-1}$ ) calculated from historical hydrographic data; (b) station positions from which (a) was calculated from; (c) OCCAM mean geopotential anomaly field; (d) difference between the OCCAM mean field and the historical data field ((c)-(a), magnitude greater than $1 \mathrm{~J} \mathrm{~kg}^{-1}$ is shaded); (e) POCM_4C mean geopotential anomaly field; (f) difference between the POCM_4C mean field and the historical data field ((e)-(a), shading as in (d)). Contour interval of $0.5 \mathrm{~J} \mathrm{~kg}^{-1}$ in (a), (c), (e), and $1 \mathrm{~J} \mathrm{~kg}^{-1}$ in (d), (f). Bathymetry shallower than $1000 \mathrm{~m}$ is filled grey, land is black.

the available output at the time of the study; Fig. 2(c)) and from the monthly mean fields over the simulation period of POCM_4C (1979-1998; Fig. 2(e)). To facilitate visualisation of the areas of disagreement between the models and the historical geopotential anomaly field, difference fields 
were generated by gridding the model output onto the historical data grid and then subtracting the historical field (Fig. 2(d) and (f)).

The large-scale flow depicted by the historical geopotential anomaly $(\Delta \Phi)$ field (Fig. 2(a)) is generally similar to that shown by Gordon et al. (1978), Olbers et al. (1992) and Orsi et al. (1995). The northern part of the ACC $\left(\Delta \Phi \geqslant 6 \mathrm{~J} \mathrm{~kg}^{-1}\right)$ makes a northward detour around the Falkland Plateau with the Subantarctic Front and Polar Front, the strongest of the ACC jets, visible as sharp gradients in the geopotential anomaly contours. The southern part of the ACC $(\Delta \Phi \leqslant 4$ $\mathrm{J} \mathrm{kg}^{-1}$ ) flows in a northeastward path across the central Scotia Sea. The streamlines follow an anticyclonic loop around the shelf of South Georgia before retroflecting north of South Georgia. The influence of the South Sandwich Island Arc is clear in the deflection of the southern part of the ACC northwards at $30^{\circ} \mathrm{W}$.

The mean geopotential anomaly field calculated from the OCCAM output shows marked differences from the corresponding mean historical field in the Scotia Sea (Fig. 2(c) and (d)). Tight bunching of the geopotential anomaly contours in northern Drake Passage brings denser southern waters further north in OCCAM than in the hydrographic data. This meander/eddy is an artefact of the model's local bathymetry (D. Webb, personal communication) and can be observed in other numerical models of the region (e.g. Fine Resolution Antarctic Model, Grose et al. (1995)). An anomalously raised sea surface is found across almost the entire Scotia Sea. This displaces the geopotential anomaly contours in the central Scotia Sea southwards, forcing the southern part of the ACC and the associated fronts to flow along the South Scotia Ridge rather than through the centre of the basin, and causing some flow from southern Drake Passage south of the South Orkney Plateau. Away from the influence of this anomalous geopotential increase however, flow east and north of South Georgia is similar in OCCAM to the historical data with water flowing westward along the northern coast of South Georgia before retroflecting at $36^{\circ} \mathrm{W}$, comparable to the historical field.

The mean POCM_4C geopotential anomaly field also exhibits bunching of the geopotential anomaly contours in northern Drake Passage but the southern part of the flow is less affected than in OCCAM and remains more southerly in POCM_4C (Fig. 2(e) and (f)), maintained by an unsubstantiated, locally relatively shallow bank $(<3000 \mathrm{~m})$ in Drake Passage in POCM_4C (Fig. 1(d)). Across the Scotia Sea, there is predominantly northeastward flow in POCM_4C and until $35^{\circ} \mathrm{W}$ the positions of the geopotential anomaly contours of the southern ACC $\left(\Delta \Phi \leqslant 5 \mathrm{~J} \mathrm{~kg}^{-1}\right)$ correlate well with the historical data. However, POCM_4C fails to simulate the northward steering of the southern ACC in the eastern Scotia Sea and the circulation northeast of South Georgia: the flow of the southern ACC front (SACCF; approximated by $\Delta \Phi \simeq 4.75 \mathrm{~J} \mathrm{~kg}^{-1}$ ) and the southern ACC does not wrap around South Georgia and retroflect north of the island as it does in the hydrographic data.

\section{2. $1000-2000 m$ averaged velocity}

The model flow fields averaged over 1000-2000 m illustrate the main pathways of the ACC (Fig. 3(a) and (b)). The depth-averaged fields were calculated from all model levels with midpoints in the range 1000-2000 m from the mean monthly April 1995 velocity fields. For OCCAM this is levels 18-22, for POCM_4C levels 12-14 were used. The flow pathways in these monthly 

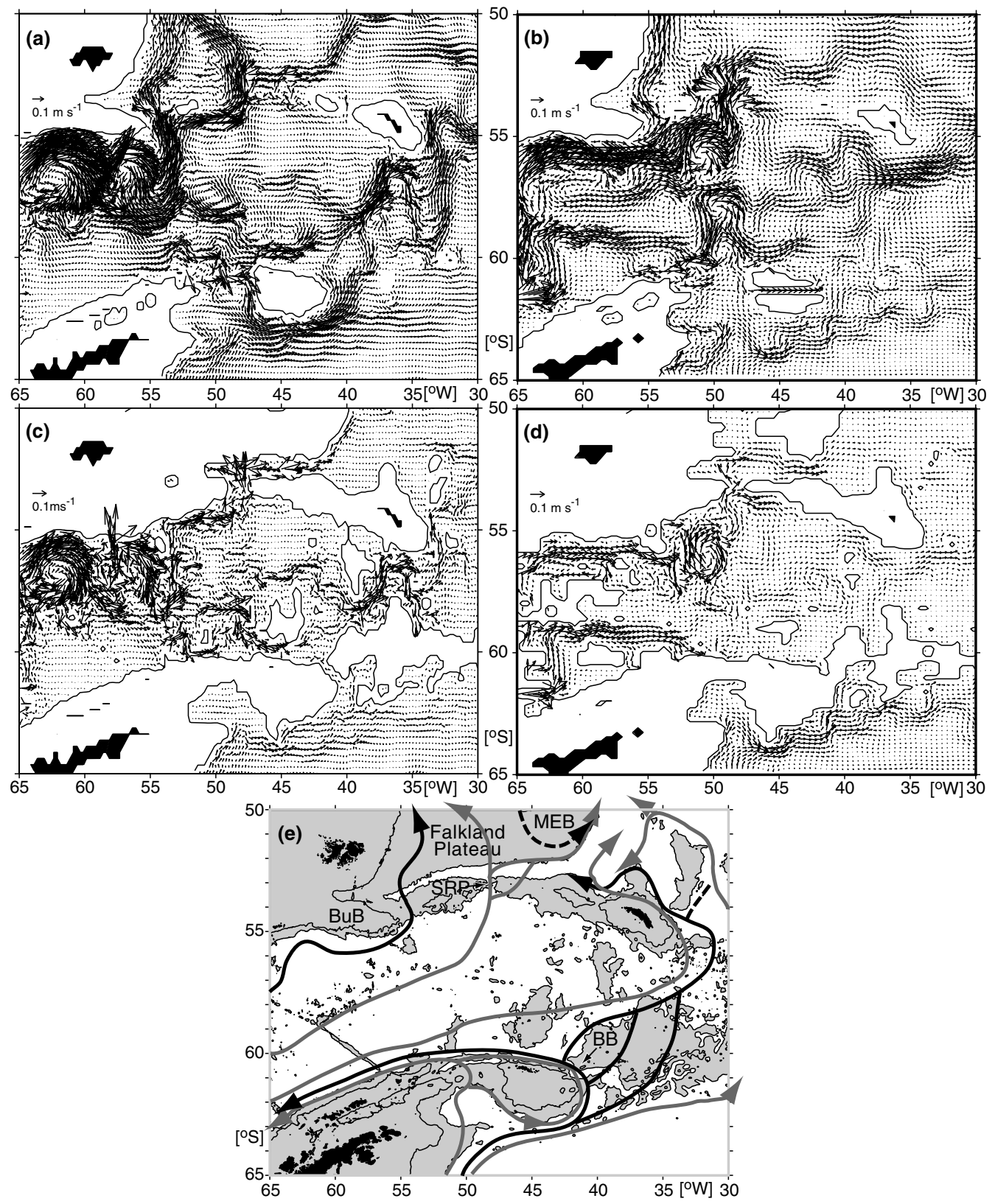

Fig. 3. Horizontal circulation at depth: (a) Horizontal velocity averaged over 1000-2000 $\mathrm{m}$ in OCCAM (levels 18-22). The 1000 m OCCAM isobath is marked; (b) as (a) but POCM_4C output (levels 12-14); (c) as (a) but averaged over depths greater than $3000 \mathrm{~m}$ (levels 27-36). The $3000 \mathrm{~m}$ OCCAM isobath is marked; (d) as (c) but for POCM_4C (levels 16-20). All model output shown is from the mean monthly April 1995 fields. (e) Schematic of deep pathways in the Scotia and Weddell Seas reproduced from Naveira Garabato et al. (2002). Dashed lines indicate sporadic or unconfirmed pathways. The $1000 \mathrm{~m}$ isobath is marked, bathymetry shallower than $3000 \mathrm{~m}$ is shaded grey. Bathymetric features marked are BB-Bruce Bank, BuB - Burdwood Bank, MEB-Maurice Ewing Bank, and SRP—Shag Rocks Passage. 
mean fields have the same general characteristics as annual mean fields from both models, but we show April 1995 to coincide with the WOCE hydrographic section discussed later.

In OCCAM, flow at 1000-2000 m (Fig. 3(a)) is dominated by the recirculation in northern Drake Passage $\left(\sim 63^{\circ} \mathrm{W}, 57^{\circ} \mathrm{N}\right)$, noted above in the geopotential anomaly field (Fig. 2(c)). In northern Drake Passage, the Subantarctic and Polar Fronts are merged, separating at the passage east of Burdwood Bank $\left(\sim 53^{\circ} \mathrm{W}\right)$. The Subantarctic Front follows a realistic path close to the $2000 \mathrm{~m}$ isobath of the Falkland Plateau. The Polar Front crosses the North Scotia Ridge via Shag Rocks Passage $\left(\sim 47^{\circ} \mathrm{W}\right)$ and the associated flow then divides into two similarly sized branches. One branch flows north over the Falkland Plateau, the other follows the southern flank of the Maurice Ewing Bank, in agreement with observations (Arhan et al., 2002). The jets of the SACCF and the southern boundary of the ACC (SB) are merged in OCCAM in the central Scotia Sea, flowing along the northern flank of the South Scotia Ridge. The jets separate east of South Georgia; the SACCF follows the northern shelf of the island westward before retroflecting at $\sim 37^{\circ} \mathrm{W}$. The SB takes an eastward course out of the study region.

In the Weddell Sea, the OCCAM flow between 1000 and $2000 \mathrm{~m}$ is dominated by a strong current south of the South Orkney Plateau. Water from the southern ACC crosses the South Scotia Ridge west of the South Orkney Islands to join the topographically steered flow, as implied by the geopotential anomaly data (Fig. 2(c)). East of the plateau there is northward flow through Orkney Passage $\left(\sim 40^{\circ} \mathrm{W}\right)$ which is deflected either side of the $1500 \mathrm{~m}$ (shallowing in places to $<1000 \mathrm{~m})$ deep Bruce Bank $\left(\sim 41^{\circ} \mathrm{W}, 60.5^{\circ} \mathrm{S}\right)$.

POCM_4C does not simulate the eddy observed in the OCCAM flow fields (Fig. 3(b)) and a greater proportion of the flow through Drake Passage is via the southern part of the passage, as noted in the surface flow from the geopotential anomaly data (Fig. 2(e)). As with OCCAM, the Subantarctic Front follows the isobaths of the Falkland Plateau once separated from the Polar Front at Burdwood Bank. The Polar Front splits into three branches in POCM_4C. Some of the associated flow goes north over the Falkland Plateau, the majority of the transport follows the southern flank of the Maurice Ewing Bank, and the rest of the flow associated with the Polar Front is diverted south by the North Scotia Ridge. Downstream of the Maurice Ewing Bank, most of the transport associated with the major branch of the Polar Front is sent to the southeast flowing unrealistically along the northern shelf of South Georgia. The zonal nature of the flow in the eastern Scotia Sea in POCM_4C noted from the geopotential anomaly field is evident in the 1000-2000 m circulation field. The channel through the South Orkney Passage noted above allows an unrealistic zonal passage for eastward-flowing waters of the southern ACC. In the Weddell Gyre, the flow is better resolved by POCM_4C than OCCAM; the current south of the South Orkney Plateau is weaker with less southward flow from the ACC into the Weddell Gyre. However, there is less northward exchange through Orkney Passage in POCM_4C with most of the Weddell Gyre water continuing eastward along the southern flank of the South Scotia Ridge.

\section{3. $3000 m$ and deeper averaged velocity}

The model pathways of deep water are illustrated in the depth-averaged horizontal flow fields for depths greater than $3000 \mathrm{~m}$ (Fig. 3(c) and (d)), calculated from the bottom 10 levels of OCCAM and the bottom 5 levels of POCM_4C from the mean April 1995 velocity fields. As with the 
1000-2000 m averages, the April 1995, $3000 \mathrm{~m}$ and deeper averages are little different from annual mean data.

The circulation at depth in OCCAM (Fig. 3(c)) compares well with pathways derived from hydrographic data collected in the Scotia Sea (Naveira Garabato et al., 2002, Fig. 3(e)). Eastward flow along the southern flank of the South Scotia Ridge is simulated with northward exchange through Orkney Passage. There is some flow westward along the northern flank of the South Orkney Plateau and some east along the northern flank of the South Scotia Ridge. Deep waters flow around the flank of the Falkland Plateau and the Maurice Ewing Bank, and there is northward flow along the eastern shelf of South Georgia into the Georgia Basin. The eddy observed in northern Drake Passage in the near-surface geopotential anomaly field and the 1000$2000 \mathrm{~m}$ averaged velocity field is a full-depth feature.

The problems with the bathymetry of POCM_4C are further illustrated (Fig. 3(d)): much of Drake Passage is shallower than in both the ocean and in OCCAM, there are no gaps through the South Scotia Ridge and the wide passage through the Falkland Plateau is too deep ( $>3000 \mathrm{~m} \mathrm{cf}$. $<2750 \mathrm{~m}$ in the ocean). These features influence the circulation at depth in POCM_4C. There are no routes for denser bottom waters to exit the Weddell Sea into the Scotia Sea; shallower waters can overflow the ridge as indicated by the westward flow along the South Orkney Plateau. Southward flow of bottom waters into the Falkland Trough (between the Falkland Plateau and the North Scotia Ridge) is permitted by the gap in the Plateau; these waters join the deep flow associated with the Polar Front to flow east along the southern flank of the Falkland Plateau before continuing to the east at $\sim 52^{\circ} \mathrm{S}$ instead of veering north around the Maurice Ewing Bank (Fig. 3(d)). There is no northward flow of bottom waters into the Georgia Basin along the eastern side of South Georgia, instead the flow at depth is southward following the bathymetric contours associated with South Georgia. Neither model reproduces the observed westward flow of bottom water out of the Scotia Sea and along the Antarctic Peninsula.

\subsection{Sea surface height variability}

To investigate the levels of variability present in the models in this region we compare standard deviation fields calculated from model sea surface height with satellite altimetry data (Fig. 4). The satellite variability field is calculated from 3 years (1993-1995) of 10 day fields of sea surface height anomaly data from TOPEX/POSEIDON (AVISO, 1996, 1998; Le Traon et al., 1998), gridded at a resolution of $\frac{1}{4}^{\circ} \times \frac{1}{4}^{\circ}$. The OCCAM variability field is calculated as the standard deviation of all available mean 5 day sea surface height fields over the same 3 year period (19931995) and the POCM_4C field, provided by R. Tokmakian, is the standard deviation of 4 years (1992-1995) of mean 3 day sea surface height fields. Examination of the OCCAM data revealed that the sea surface height field drifts over time (c.f. Saunders et al., 1999), with an average rate of $-5.55 \mathrm{~cm} \mathrm{year}^{-1}$ over the study region. This drift was removed by linearly detrending the sea surface height data before calculating the variability field. The sea surface of POCM_4C is not expected to drift because of the corrections applied in the model for imbalances in heat and freshwater.

The satellite data show high variability associated with the Subantarctic Front and the Polar Front extending from Drake Passage through the Scotia Sea and north of South Georgia, with lower variability elsewhere (Fig. 4(a)). Variability is observed in association with two passages 

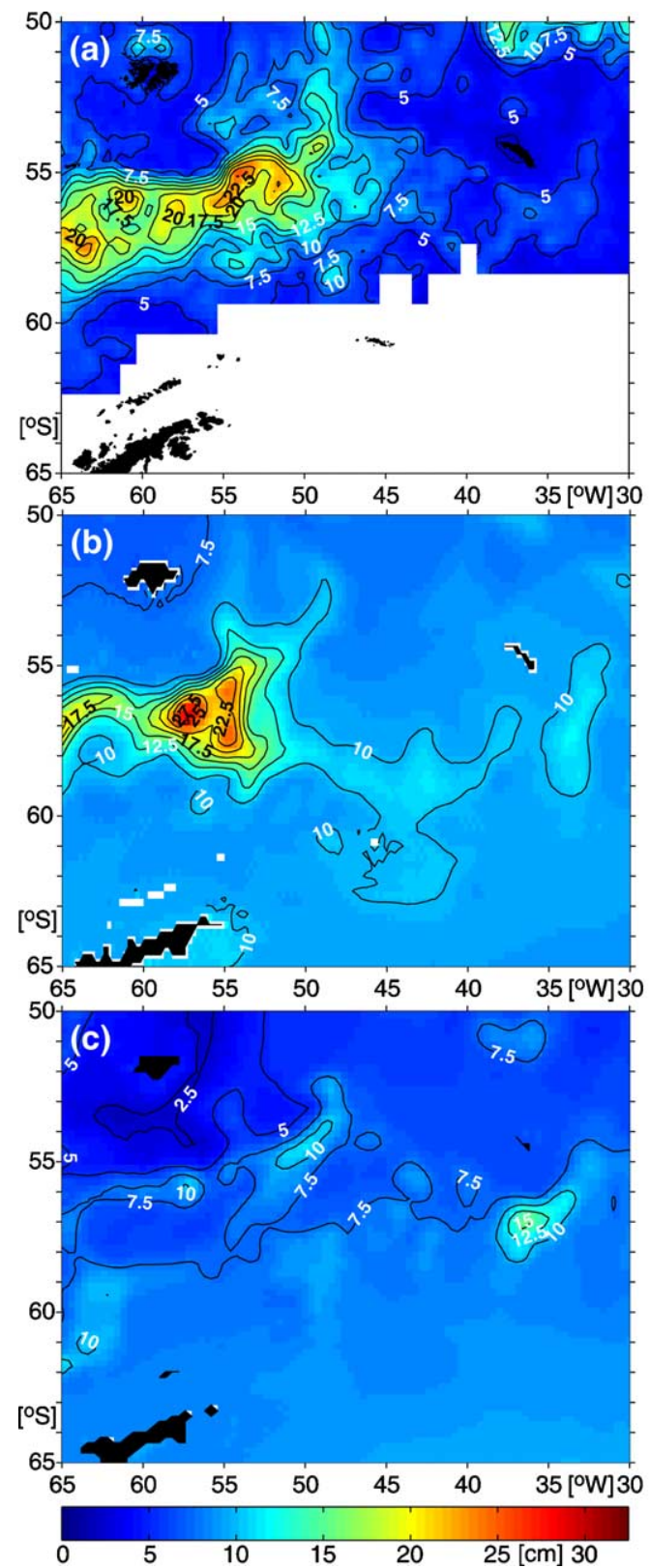

Fig. 4. Sea surface height variability (cm). (a) TOPEX/POSEIDON data for the period 1993-1995; (b) OCCAM output for the period 1993-1995; (c) POCM_4C output for the period 1992-1995.

through the North Scotia Ridge (east of Burdwood Bank and Shag Rocks Passage, see Fig. 3(e) for locations). The lack of data over much of the southern part of the study region is related to the seasonal sea-ice cover and the spatial coverage of the satellite. OCCAM captures the area of maximum sea surface height variability but slightly overestimates the peak value $(>27.5 \mathrm{~cm}$ cf. 
$>25 \mathrm{~cm}$ ) and concentrates it over a smaller region. In POCM_4C, the maximum values in this region are significantly underestimated by the model $(>10 \mathrm{~cm})$. Both models exhibit variability associated with the deeper passages through the North Scotia Ridge. Maximum variability in POCM_4C is associated with the SACCF south of South Georgia. Such a region is apparent in the satellite data, though with smaller peak value. POCM_4C also reproduces the variability associated with the Polar Front north of South Georgia. Both models have higher background variability than the satellite data.

\section{Water mass characteristics, distributions and fronts}

\subsection{Data}

To examine the reproduction and distribution of the regional water masses in the models, together with the characteristics of the fronts, we compare model output with high quality hydrographic data from a subsection of WOCE section A23 (Heywood and King, 2002). A23, a long quasi-meridional transect from Antarctica to Brazil, was conducted from RRS James Clark Ross between March and May 1995. We use data from a subsection of the cruise across the eastern Scotia Sea between 05 and 14 April 1995 (Stations 25-64; Fig. 1(a)). Temperature and salinity were recorded with a Neil Brown MkIIIb CTD profiler, accurate to 0.001 and $0.002{ }^{\circ} \mathrm{C}$ respectively. A full description of the A23 section is provided by Heywood and King (2002).

Sections of OCCAM and POCM_4C potential temperature $(\theta)$, salinity $(S), u$ and $v$ (the components of total velocity in the $x$ and $y$-directions respectively; used to calculate the crosstrack component of absolute velocity) have been created by bilinearly interpolating the model output from the four nearest grid cells onto the A23 station locations. Output was extracted from the monthly mean April 1995 OCCAM and POCM_4C fields. Geostrophic velocity relative to the deepest common level between station pairs and the associated baroclinic transport have been calculated from the potential temperature and salinity output. The absolute velocity and total transport are also available from the models.

\subsection{Water mass characteristics and distribution}

Data from the A23 section (Fig. 5(a)) show a clear distinction between waters of the ACC (generally above $0{ }^{\circ} \mathrm{C}$; red and blue lines) and those found to the south in the Weddell-Scotia Confluence and the Weddell Gyre (generally below $0{ }^{\circ} \mathrm{C}$; black and magenta lines). There is a clear separation in Antarctic Surface Water (AASW) and the intermediate waters between the two regimes. Within the section, three types of Winter Water (WW; a remnant of winter cooling and mixing that is marked by a subsurface $\theta$-minimum (Sievers and Nowlin, 1984)) are evident, two in the ACC waters (red and blue lines) with differing salinities marking the presence of the SACCF (Heywood and King, 2002; Thorpe et al., 2002) and one south of the ACC (black and magenta lines) close to the freezing point. Together AASW and WW occupy the upper $200 \mathrm{db}$ of the water column (Fig. 6(a)).

Below the AASW and WW lies Circumpolar Deep Water, the most voluminous water mass of the section. Upper Circumpolar Deep Water (UCDW, recognised by its subsurface temperature 

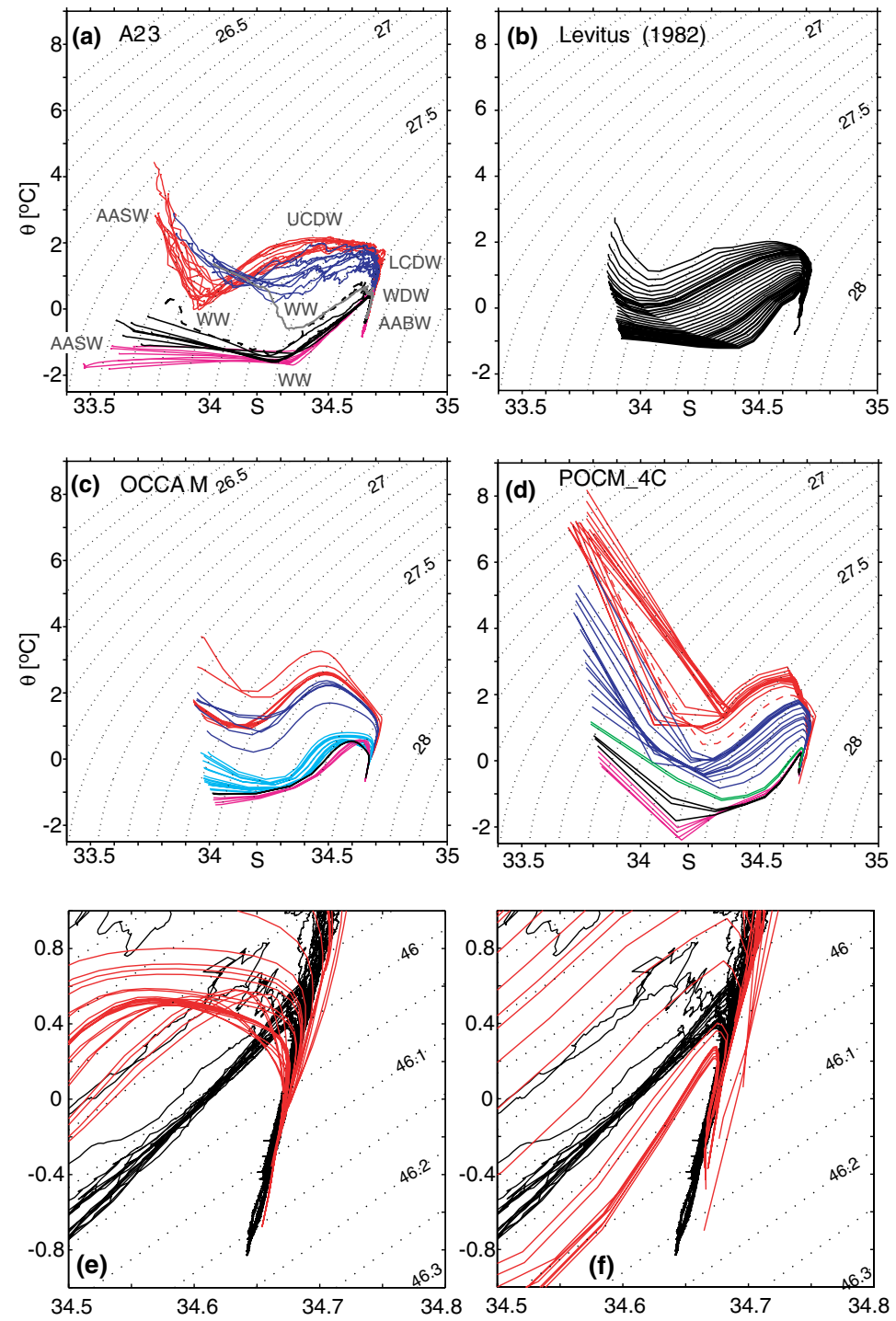

Fig. 5. $\theta-S$ profiles for the A23 and model sections, colour-coded (in a, c, d) according to frontal positions: red-north of the southern ACC front (SACCF), dark blue-between the SACCF and the southern boundary of the ACC (SB), black - Weddell-Scotia Confluence (WSC), magenta - south of the Weddell Front (WF), dashed profiles denote stations of high mixing. (a) A23, grey profile is station 45, an eddy; (b) Levitus (1982) mean annual data from which both models were initialised; (c) OCCAM, light blue profiles are stations that sample the anomalous water mass observed in OCCAM only, between the SB and the WSC; (d) POCM_4C, green profiles are transitional between the WSC and the waters north of the SB. Water masses are marked on (a) (refer to text for abbreviations) and potential density contours (dotted lines) are marked in $(\mathrm{a}-\mathrm{d})$. Detailed plots of the bottom waters are given in (e,f); the A23 data are plotted in black and the model data in red (note that the axes are different to (a-d)). (e) OCCAM; (f) POCM_4C. Potential density relative to $4000 \mathrm{db}$ is contoured (dotted lines).

maximum) is centred on $400 \mathrm{db}$ in the A23 data (Fig. 6(a)). Orsi et al. (1995) report that the position of the SACCF can be located from properties of the UCDW with stations north of the 

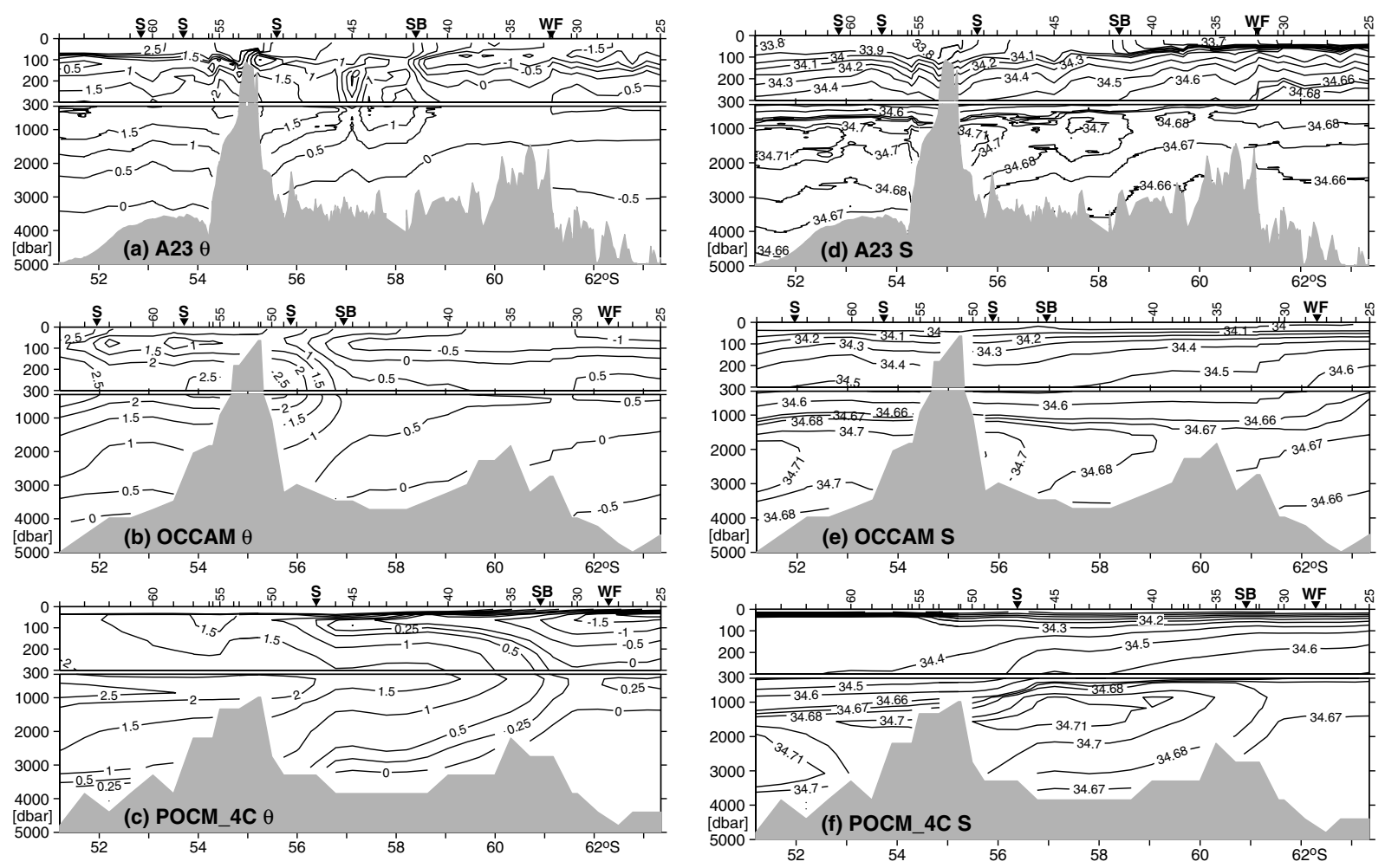

Fig. 6. Full depth vertical property sections of the A23 and model sections: (a) A23 potential temperature $\left(\theta ;{ }^{\circ} \mathrm{C}\right.$ ); (b) OCCAM $\theta\left({ }^{\circ} \mathrm{C}\right)$; (c) POCM_4C $\theta\left({ }^{\circ} \mathrm{C}\right)$; (d) A23 salinity $(S)$; (e) OCCAM $S$; (f) POCM_4C $S$. Bathymetry (from the onboard echosounder for the A23 data and the models otherwise) is filled grey. Station numbers are marked in the upper axes. S, SB and WF denote the positions of the SACCF, SB and WF respectively in each section. The WeddellScotia Confluence lies between the SB and WF.

front having a subsurface temperature-maximum greater than $1.8^{\circ} \mathrm{C}$. This criterion does apply for the northern two crossings of the SACCF in the A23 data but misplaces the southern crossing of the front by two stations. The southern terminus of UCDW at $58.5^{\circ} \mathrm{S}$ marks the presence of the SB (Orsi et al., 1995). Beneath UCDW lies Lower Circumpolar Deep Water (LCDW), identified by a subsurface salinity maximum $(S>34.7$ in the A23 data). LCDW shoals southward in the A23 section from $1500 \mathrm{db}$ in the Georgia Basin in the north of the section to $1000 \mathrm{db}$ by the position of the SB. A modified form of LCDW is found south of the SB, centred on a pressure of $300 \mathrm{db}$. This water mass, Warm Deep Water (labelled WDW on Fig. 5(a)), has been cooled in the Weddell Gyre since leaving the ACC. The deepest water mass observed in the A23 data is Antarctic Bottom Water (labelled AABW on Fig. 5(a)), with potential temperatures less than $0{ }^{\circ} \mathrm{C}$.

Both models were initialised from Levitus (1982) annual mean temperature and salinity data (Fig. 5(b)). $\theta-S$ profiles for the A23 stations derived from the $1^{\circ} \times 1^{\circ}$ atlas data vary smoothly; the procedure of gridding data taken at different times into $1^{\circ}$ cells has smeared out the sharp fronts. The effect of seasonality on the surface and WW $\theta-S$ properties can be seen by comparing the Levitus (1982) and A23 data (lower salinity in the A23 section for both water masses because of 
seasonal ice melt). How then have the water mass characteristics developed in the models from this starting point?

In OCCAM (Fig. 5(c)) there is a clear separation of the ACC waters (red and blue lines) and the Weddell-Scotia Confluence/Weddell Gyre waters further south (light blue, black and magenta lines) although the transition between the different water masses is too smooth compared with the A23 data. Surface salinity remains too saline, particularly south of the ACC, and has increased during the model run by approximately 0.05 from the Levitus (1982) values but surface temperatures are realistic. Without a sea-ice model, it is difficult to reproduce the seasonal ice melt signal which drives salinity changes in the AASW. In the ACC there is only one type of WW (as there is in the Levitus (1982), Fig. 5(b), and Levitus and Boyer (1994) and Levitus et al. (1994) data to which OCCAM was later relaxed to (not shown)) with salinity in the range 34.1-34.2, intermediate between the two observed types in A23. There is no temperature-minimum signal of WW in the southern stations of the section. The AASW and WW occupy the upper $200 \mathrm{db}$ of the water column in OCCAM as they do in the A23 section (Fig. 6(b)).

UCDW, centred on the same pressure in OCCAM as in the A23 data, has become warmer in OCCAM with potential temperatures at the subsurface temperature-maximum north of the SACCF greater than $2.5^{\circ} \mathrm{C}$ (Fig. 5(c)). The three crossings of the SACCF in the OCCAM section are each within two stations of the frontal crossings in the A23 section (Fig. 6(b)). The small displacements of the northern and southern crossings of the front in the model are most likely to be due to the model's smoother bathymetry (the front appears strongly steered by topography) but also, the model may not depict exactly the meander in the ocean current. The southern limit of UCDW, marking the $\mathrm{SB}$, is at $\sim 56.8^{\circ} \mathrm{S}$, almost $200 \mathrm{~km}$ north of the corresponding position in A23. The SB can also be located in OCCAM by the sharp change in AASW temperature $(\theta>0.5$ ${ }^{\circ} \mathrm{C}$ north of the SB, Fig. 5(c)). South of the SB, centred on approximately $500 \mathrm{db}$, there is an anomalous water mass in OCCAM with a subsurface temperature-maximum warmer than $0.5^{\circ} \mathrm{C}$ and salinity greater than 34.5 (Figs. 5(c) and 6(b)). This water mass is present in neither the observations nor in POCM_4C.

The LCDW in OCCAM is $1000 \mathrm{db}$ deeper and much thicker than in the A23 section (Fig. 6(e)). In the Georgia Basin, it is centred on $2500 \mathrm{db}$, by $60^{\circ} \mathrm{S}$ it has shoaled to only $2000 \mathrm{db}$. Warm Deep Water is observed in OCCAM south of the anomalous waters at a similar pressure as in the observations. Changes in the $\theta-S$ properties of the Warm Deep Water locate the Weddell Front (WF): Warm Deep Water is more saline and slightly cooler in the Weddell-Scotia Confluence north of the WF in OCCAM (Fig. 5(c)). The WF is at $\sim 62.25^{\circ} \mathrm{S}$, approximately $170 \mathrm{~km}$ south of the front in A23 (close to $61^{\circ} \mathrm{S}$ (Heywood and King, 2002)). The increased volume of LCDW in OCCAM is a result of a reduction in the volume of Antarctic Bottom Water $\left(\theta<0{ }^{\circ} \mathrm{C}\right)$, particularly in the Georgia and Scotia basins (north of $60^{\circ} \mathrm{S}$ ). The bottom waters in OCCAM have $\theta-S$ properties very close to the observations (Fig. 5(e)) which converge on a single curve as in the A23 data.

POCM_4C has fewer vertical levels than OCCAM (20 cf. 36; Table 1) and does not represent the water mass structure of the study region as well as OCCAM does. There is a strong gradient between the upper and second model levels in both temperature and salinity (Figs. 5(d) and 6(c) and (f)) which suggests insufficient vertical mixing. The $\theta-S$ properties in POCM_4C vary much more smoothly along the section (Fig. 5(d)). Sea surface salinity is more realistic than in OCCAM but the range of values is still smaller than observed in A23. Sea surface temperature is almost 
$2{ }^{\circ} \mathrm{C}$ warmer in POCM_4C than in the observations everywhere along the section. WW is present in the POCM_4C section but it is too fresh $(S \simeq 34.18 \mathrm{cf}$. 34.35) and too cold in the south of the section $\left(\theta<-2{ }^{\circ} \mathrm{C}\right.$ which is colder than the freezing point for a salinity of 34.18 and pressure of $100 \mathrm{db}$ ). Its salinity and temperature increase with latitude until at the very north of the section the WW has $\theta \simeq 1.5^{\circ} \mathrm{C}, S \simeq 34.35$, very different to the observations. Referring back to the horizontal circulation maps (Figs. 2(e) and 3(b)), this anomalous northern water mass, occupying the upper $300 \mathrm{db}$ of the water column, appears to be associated with the northern ACC.

UCDW in POCM_4C is centred at $750 \mathrm{db}$, deeper than in both the A23 and OCCAM sections. As with OCCAM, the POCM_4C UCDW is warmer than the observations but it is also more saline $(S>34.6)$. The southern limit of UCDW, and hence the SB, in POCM_4C is at approximately $61^{\circ} \mathrm{S}$, more than $150 \mathrm{~km}$ south of the A23 position. The SACCF, distinguishable by both UCDW $\theta>2{ }^{\circ} \mathrm{C}$ and WW $\theta>0.5{ }^{\circ} \mathrm{C}$ to the north of the front, is crossed only once in the POCM_4C section, at $56.4^{\circ} \mathrm{S}$ (two stations south of the southern crossing in A23). Below the UCDW, LCDW in POCM_4C is very deep in the Georgia Basin, centred on approximately 3000 $\mathrm{db}$. South of South Georgia $\left(55^{\circ} \mathrm{S}\right)$ it shoals rapidly to $1000 \mathrm{db}$, comparable to the A23 data. The modified form of LCDW, Warm Deep Water, is $200 \mathrm{db}$ deeper in POCM_4C than in both the A23 and OCCAM sections. Small changes in its $\theta-S$ properties place the $\mathrm{WF}$ at $62.25^{\circ} \mathrm{S}$, the same location as in the OCCAM section. The $\theta-S$ properties of the bottom waters in POCM_4C are very different to both the A23 data and to OCCAM (Fig. 5(f)). The stations within the Weddell Gyre have bottom water that is up to $0.3{ }^{\circ} \mathrm{C}$ warmer than observed in the A23 section, and is hence less dense. Due to the lack of deep water pathways through the South Scotia Ridge, the bottom water in the northern stations of the subsection originates from a different source and is more saline by at least 0.02 .

Both A23 and a subsequent repeat of part of the section occupied four years later (Meredith et al., 2001) observed an eddy at $\sim 57^{\circ} \mathrm{S}$ (station 45). Meredith et al. (2001) propose that its persistence suggests that it is possibly a permanent feature, perhaps located to local bathymetry but they found no feature they thought likely to be responsible. The eddy is present in both models in a similar location (although only weak in OCCAM so that it does not show up in the contouring) but again there is no obvious feature in the local bathymetry of either model that could be a possible cause.

\subsection{Velocity structure and transports}

Geostrophic velocity and its associated baroclinic transport are shown in Fig. 7 for the A23 and model sections. Also shown are absolute velocity and its derived transport for the two model sections; comparable data are not available from A23 (Heywood and King, 2002). Details of the maximum velocities and transport associated with the fronts crossed in the hydrographic section are given in Table 2.

Both models overestimate the geostrophic velocity and baroclinic transport associated with the SACCF (apart from the second crossing of the SACCF in the OCCAM section which catches the SACCF at its turning point thus velocity and hence transport perpendicular to the section are small). The jets associated with the SACCF are much broader and extend to greater depth in the models than in the hydrographic data (Fig. 7). Absolute velocity and transport at the northern two crossings of the SACCF in OCCAM are similar to the geostrophic and baroclinic transports 

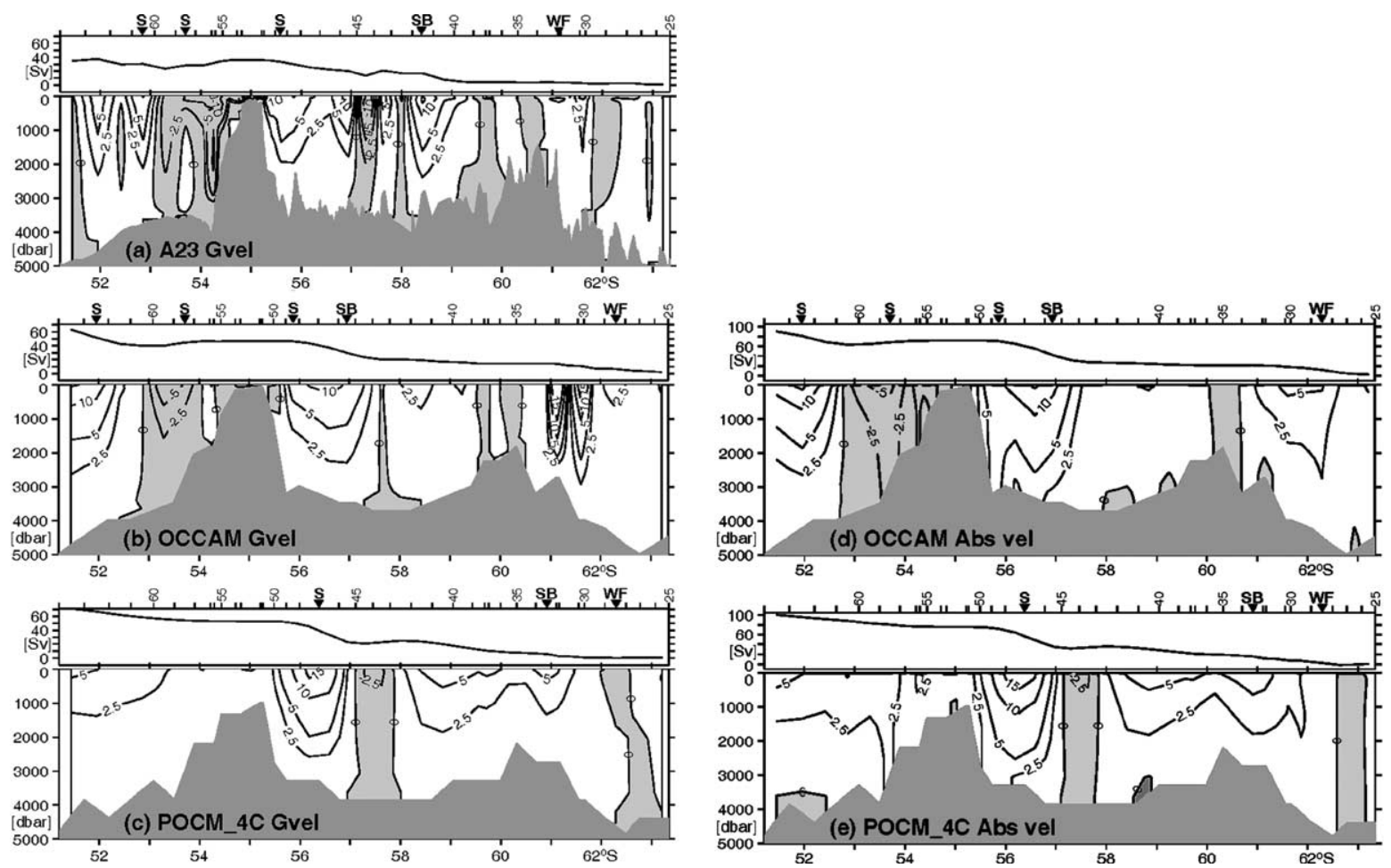

Fig. 7. (a) A23 geostrophic velocity $\left(\mathrm{cm} \mathrm{s}^{-1}\right)$ referenced to the deepest common level between station pairs (negative values (shaded) indicate westward flow). Cumulative baroclinic transport (Sv; summed from south to north) is plotted in the upper panel; (b) as (a) but OCCAM; (c) as (a) but POCM_4C; (d) cross-track component of absolute velocity from OCCAM ( $\mathrm{cm} \mathrm{s}^{-1}$; negative values (shaded) indicate westward flow). Cumulative total transport is plotted in the upper panel (Sv; summed from south to north); (e) as (d) but POCM_4C. Bathymetry (from the onboard echosounder for the A23 data and the models otherwise) is filled grey. Station numbers and frontal positions are marked in the upper axes as in Fig. 6.

(Table 2) suggesting that only a small part of the transport associated with the front is barotropic; in POCM_4C the SACCF has a greater barotropic contribution. The third crossing of the $\mathrm{SACCF}$ is merged with the SB in OCCAM, giving a large absolute transport. The baroclinic transport associated with the merged jets is consistent with that of the northern crossing of the SACCF implying that the SB contributes the greater part of the barotropic transport. The geostrophic velocity and baroclinic transport associated with the SB in POCM_4C are approximately $50 \%$ of the A23 values.

The southernmost front crossed in the hydrographic section is the WF, separating the waters of the Weddell Sea from those of the Weddell-Scotia Confluence. In the A23 data, the WF is associated with insignificant geostrophic velocity and baroclinic transport (Heywood and King, 2002). North of the WF in OCCAM, there are two anomalous strong, narrow jets in which the geostrophic velocity exceeds $0.33 \mathrm{~m} \mathrm{~s}^{-1}$. These features are merged with the WF in the absolute velocity section (Fig. 7(d)), giving rise to a relatively large absolute transport for the WF. In POCM_4C, as in the A23 data, the WF has no associated jet in geostrophic velocity and only slow 
Table 2

Details of the fronts crossed by the hydrographic and model A23 sections

\begin{tabular}{|c|c|c|c|c|c|c|c|}
\hline \multirow[t]{2}{*}{ Front } & \multirow[t]{2}{*}{ Section } & \multirow[t]{2}{*}{ Position } & \multirow[t]{2}{*}{ Stations } & \multirow{2}{*}{$\begin{array}{l}\operatorname{Max} V_{\mathrm{g}} \\
\left(\mathrm{m} \mathrm{s}^{-1}\right)\end{array}$} & \multirow{2}{*}{$\begin{array}{l}\operatorname{Max} V_{\text {abs }} \\
\left(\mathrm{m} \mathrm{s}^{-1}\right)\end{array}$} & \multicolumn{2}{|c|}{ Transport (Sv) } \\
\hline & & & & & & Baroclinic & Total \\
\hline \multirow[t]{7}{*}{ SACCF } & A23 & $52.75^{\circ} \mathrm{S}$ & $60-61$ & 0.10 & - & 16.5 & - \\
\hline & & $53.75^{\circ} \mathrm{S}$ & $58-59$ & -0.075 & - & -12.9 & - \\
\hline & & $55.5^{\circ} \mathrm{S}$ & $49-50$ & 0.10 & - & 14.2 & - \\
\hline & OCCAM & $52^{\circ} \mathrm{S}$ & $62-63$ & 0.16 & 0.18 & 23.9 & 27.0 \\
\hline & & $53.75^{\circ} \mathrm{S}$ & $58-59$ & -0.08 & -0.06 & -6.5 & -6.9 \\
\hline & & $56.25^{\circ} \mathrm{S}$ & $48-49$ & 0.12 & 0.19 & 26.6 & 44.6 \\
\hline & POCM_4C & $56.4^{\circ} \mathrm{S}$ & 47 & 0.16 & 0.21 & 32 & 44.2 \\
\hline \multirow[t]{3}{*}{ SB } & A23 & $58.5^{\circ} \mathrm{S}$ & $41-42$ & 0.15 & - & 16.1 & - \\
\hline & OCCAM & $56.8^{\circ} \mathrm{S}$ & $45-46$ & 0.12 & 0.19 & 26.6 & 44.6 \\
\hline & POCM_4C & $60.9^{\circ} \mathrm{S}$ & $33-34$ & 0.06 & 0.07 & 8 & 10.6 \\
\hline \multirow[t]{3}{*}{ WF } & A23 & $61^{\circ} \mathrm{S}$ & $32-33$ & 0.08 & - & $<1$ & - \\
\hline & OCCAM & $62.25^{\circ} \mathrm{S}$ & $28-29$ & 0.05 & 0.06 & 4.6 & 15.5 \\
\hline & POCM_4C & $62.25^{\circ} \mathrm{S}$ & $28-29$ & 0.0 & 0.02 & $<1$ & 3.9 \\
\hline
\end{tabular}

$V_{\mathrm{g}}$ - geostrophic velocity, $V_{\mathrm{abs}}$-cross-track component of absolute velocity. Negative values indicate westward flow/ transport. Multiple crossings of the SACCF are listed from north to south, note that in OCCAM the jets of the southernmost crossing of the SACCF and the SB are merged hence the duplicate values. Transport values calculated for the A23 data are from Heywood and King (2002). $1 \mathrm{~Sv}=10^{6} \mathrm{~m}^{3} \mathrm{~s}^{-1}$.

absolute velocities and small absolute transport. The absolute transport associated with the WF in POCM_4C of $4 \mathrm{~Sv}$ is within the uncertainty of the observed transport of 5-7 Sv determined by Heywood et al. (in press).

\subsection{Effects of temporal variability}

The hydrographic section comparison above used a mean monthly field from both models for the time of the section (April 1995), but how would using output from a different time affect the results? We have examined sea surface height variability, but what about variability in the water mass properties?

Using the 5 day/3 day mean fields available from OCCAM and POCM_4C respectively made no difference compared with the mean monthly fields. Examining mean monthly output from a month earlier or later (March/May 1995) made little difference with the OCCAM output. POCM_4C showed surface cooling (by approximately $2{ }^{\circ} \mathrm{C}$ across the whole section) over the three months. That the main differences over a three month period are in the surface properties, dependent on the model forcing, is not surprising. Considering mean monthly output from a year before and after the A23 occupation (April 1994, April 1996) does reveal noticeable differences, mainly in the properties of the WW. Given that this water mass though is a remnant of the winter mixed layer, we expect interannual differences in its characteristics. However, OCCAM also showed a significant difference in the properties of its LCDW between April 1995 and April 1996 in the northern stations of the section. By April 1996, the LCDW has become warmer and more saline $\left(\theta \simeq 1.5{ }^{\circ} \mathrm{C}, S \simeq 34.75 \mathrm{cf}\right.$. $\left.\theta \simeq 1.25^{\circ} \mathrm{C}, S \simeq 34.72\right)$. Several of the northern stations in 
POCM_4C also exhibit a similar magnitude change in the salinity of the LCDW but no change in its temperature. A more detailed evaluation of the variability of the model water mass properties with time would be useful to further extend this research.

\section{Discussion}

Although the two models under consideration (OCCAM and POCM_4C) have similar formulations, the differences in their configuration and the disparate forcing applied create some large differences from the hydrographic data and each other.

The two models differently simulate the horizontal circulation of the study region. The reduced volume of Antarctic Bottom Water in OCCAM, observed in the A23 section comparison, results in slumping of the water masses above and the creation of an anomalous water mass, which together have an adverse effect on the model circulation in the central/southern Scotia Sea forcing much of the flow along the South Scotia Ridge. There are two known problems of OCCAM that likely contribute to this: insufficient formation of Antarctic Bottom Water (Webb et al., 1998) and spurious diapycnal mixing, associated with the numerical advection scheme and horizontal diffusion, that causes the deep and bottom waters in the Southern Ocean to disappear at rates of up to $50 \mathrm{~Sv}$ (Lee et al., 2002). The latter means that even if the bottom waters were being formed properly (by using improved surface fluxes and a better representation/parameterisation of the deep and bottom water formation process, possibly including a sea-ice model) the bottom water would still dissipate in the model. Correcting this spurious mixing problem is a big challenge but important to ensure both realistic water mass properties and circulation.

The circulation in POCM_4C suffers from poor bathymetric representation. Key channels in the South Scotia Ridge are either unresolved or too shallow (e.g. the Orkney Passage), while the South Sandwich Island Arc (at $27^{\circ} \mathrm{W}$, just east of the study region) is too deep. Although some of the differences could be related to the poorer vertical resolution, there are a number of locations where this is not a cause. The deep gaps in the South Scotia Ridge are essential for northward water mass exchange (e.g., Naveira Garabato et al., 2002); a manual checking scheme of the key sills and channels, such as that employed in OCCAM (Webb et al., 1998), seems to be a vital component in the creation of a model's bathymetry. The South Sandwich Island Arc is responsible for steering the southern part of the ACC northwards in the eastern Scotia Sea; it needs to be shallowed by at least $500 \mathrm{~m}$ (to the same depth as it is in OCCAM) in POCM_4C to have an effect on the circulation. Correcting other problem areas mentioned earlier, such as the channels through the South Orkney and Falkland Plateaux, would also be beneficial for the circulation in POCM_4C. The effect of the poor bathymetry of POCM_4C on the model's circulation is evident in the presence of bottom waters from a different source region in the northern stations of the A23 subsection.

In both models the Subantarctic and Polar Fronts are forced too tightly against the tip of South America. Model bathymetry has been identified as a likely cause and early indications from a $\frac{1}{12}^{\circ}$ version of OCCAM suggest that the problem is greatly reduced at a higher resolution. However, as well as the increased horizontal resolution, the newer version of OCCAM has twice as many vertical levels and an improved representation of bathymetry (based upon a partial bottom cell 
scheme) than the version we examined. Therefore it is difficult to tell which of these features is most important for better resolving the flow through Drake Passage.

Ocean models characteristically underestimate background sea surface height variability (e.g., Semtner and Chervin, 1992; Stammer et al., 1996). For the versions of the models examined here though this does not appear to be a problem in the study region, with both models simulating realistic levels of background variability. These realistic levels of background variability are probably due to the increased frequency of wind forcing which improved the simulation in the OCCAM model (Webb and de Cuevas, 2003). The variability in POCM_4C is lower than in OCCAM. POCM_4C is known to have lower values of sea surface height variability in eddy rich areas such as the Southern Ocean although the reasons for this are unclear (Tokmakian and Challenor, 1999). An increase in resolution so that the models are truly eddy-resolving at high latitudes will further improve the variability (e.g., McClean et al., 1997; Maltrud and McClean, in press).

Examination of the water mass characteristics in a model allows consideration of the integrated effects of the model, e.g. how well the mixing schemes are performing, whether the surface fluxes are realistic, whether the fronts are adequately resolved. The integration times of OCCAM and POCM_4C (which were originally initialised from the same climatological data) are significantly different (about 10 years compared with more than 50 respectively for the time of the A23 comparison). In its shorter integration time, OCCAM has better resolved the fronts in the study region with a much clearer distinction between the Scotia and Weddell Sea waters. In POCM_4C, there is not such a separation between the two oceanic regimes, suggesting that perhaps there is too much lateral mixing or that the surface fluxes have been excessively smoothed.

In most cases, the water masses of our study region are represented in OCCAM and POCM_4C with similar properties to the hydrographic data. However both models have incongruous surface waters: in OCCAM they are too saline (by at least 0.12 but by 0.4 in the southern A23 stations), and in POCM_4C they are too warm (by more than $2{ }^{\circ} \mathrm{C}$ ). These discrepancies suggest that there are problems with the surface forcing used by the models. The overly strong surface gradients in POCM_4C also suggest that there is insufficient vertical mixing in POCM_4C. Although both OCCAM and POCM_4C use the same vertical mixing scheme, the effects can be exacerbated in POCM_4C because of the different methods of surface forcing that are employed in the two models (Table 1). OCCAM uses relaxation to climatology in which the surface salinity is matched to observations whereas the freshwater flux used by POCM_4C generates a stable surface layer that has to be vertically mixed by the model. However, the vertical mixing scheme underestimates near-surface mixing (Timmermann and Beckmann, 2004). The Pacanowski and Philander (1981) mixing scheme was designed for the tropics; there are other mixing schemes available (e.g. the Kprofile parameterisation of Large et al. (1994), or the additions to the Pacanowski and Philander (1981) scheme suggested by Timmermann and Beckmann (2004)) that may be more appropriate globally or for high latitudes.

Stammer et al. (1996) noted too saline surface waters (by 0.5 in the North Pacific) in POCM_4B (the predecessor to POCM_4C and from which POCM_4C was initialised), which were attributed to the lack of realistic salt fluxes in the simulation. The new forcing applied in POCM_4C seems to have cured this to some extent (although the surface waters of the southern stations in the A23 section are still a little saline, by $0.1-0.2$ ). In a comparison of POCM_4C output with Ocean Weather Station data at $50^{\circ} \mathrm{N}$, Tokmakian (1998) found that the annual cycle in the sea surface 
temperature in the model varied with a larger amplitude than the data (so that the hydrographic maxima (minima) are overestimated (underestimated) by up to $\sim 3{ }^{\circ} \mathrm{C}$ in the model). Examination of the annual sea surface temperature signal just north of South Georgia over the 20 year run of POCM_4C suggests the same with warmer and colder extrema in the model than in the ocean, in agreement with the observations of the too warm surface waters in the POCM_4C A23 section extracted from the April (late summer) data. The restoring term is used to counteract errors in surface forcing and model error. It is well known that surface fluxes in the Southern Ocean are poor and it is likely that the surface restoration term in POCM_4C is too weak in the study region.

Using accurate surface fluxes is important for a model as the characteristics of the upper ocean determine the formation and properties of the other water masses. For example, large discrepancies in the near-surface temperature and salinity fields (of $5{ }^{\circ} \mathrm{C}$ and 0.5 respectively) in the North Pacific of the POCM_4B run cause erroneous characteristics of the intermediate water (Stammer et al., 1996). The implications of inaccurate surface forcing, in this case for the simulation of WW, can also be observed in the A23 section comparisons. WW requires a realistic seasonal cycle for the model properties to be accurate. In OCCAM, there is no WW in the northern Weddell Sea. Comparison of a winter surface temperature field from the high frequency wind forced run of OCCAM with the winter climatological sea surface temperature field from the atlas of Olbers et al. (1992) shows that the surface waters of the Weddell Sea in this run of OCCAM are at least $1{ }^{\circ} \mathrm{C}$ too warm, with a patch of water east of the Antarctic Peninsula that is almost $2{ }^{\circ} \mathrm{C}$ warmer in the model. This can be traced to an error in the Levitus and Boyer (1994) sea surface temperature climatology that OCCAM is relaxed to (Table 1). In the sea surface temperature dataset there is a patch of water east of the Antarctic Peninsula that at its warmest (May) is warmer than $4{ }^{\circ} \mathrm{C}$. WW is a remnant of wintertime AASW, thus if the surface waters do not get sufficiently cold, then there will not be a $\theta$-minimum signal in the water column following that winter. Hence we do not see the subsurface $\theta$-minimum in the southern stations of the OCCAM section. In POCM_4C, the WW is unrealistically cold $\left(\theta<-2{ }^{\circ} \mathrm{C}\right)$. These very cold temperatures are likely an artefact of the lack of a sea-ice model in POCM_4C which would limit the sea-air temperature flux. Too little vertical mixing, already identified as a possible problem in POCM_4C, could also contribute.

The study region used here is close to the southern boundary of POCM_4C and therefore its buffer zone (which operates over the top $2000 \mathrm{~m}$ of the water column between $68^{\circ}$ and $75^{\circ} \mathrm{S}$, Table 1). Hence we expect that the properties of the intermediate water masses in this region of POCM_4C should not drift too much and, in agreement, we find that the $\theta-S$ characteristics of Warm Deep Water are much more sharply defined in POCM_4C than in OCCAM (compare Fig. $5(\mathrm{e})$ and (f)). However, the restoration is not successful at maintaining the properties of deep and bottom waters as evidenced by the difference between the observed and modelled Antarctic Bottom Water of the southern stations of the A23 section. These stations are south of the South Scotia Ridge and therefore the differences between the water masses are not due to the shallowness of the passages in the ridge preventing overflow of the denser water but rather to the model not producing the densest waters. In the Northern Hemisphere, subsurface restoration of the upper $2000 \mathrm{~m}$ is sufficient to ensure that the properties of the deep waters are maintained because restoration occurs to a greater depth than the sill in the Greenland-Scotia Ridge. However, in the Southern Ocean a greater depth is required. 
The fronts in the OCCAM A23 section are similarly located to those in the hydrographic data and it is pleasing to see that the SACCF wraps around South Georgia as it does in the observations. The southward shift of the water mass structure in POCM_4C may be related to the poorer bathymetric dataset used in the model and it is suggested that this is updated in future runs. The baroclinic transport through the A23 section is greater in both models than in the hydrographic data (total baroclinic transport for A23 = $35 \mathrm{~Sv}, 64 \mathrm{~Sv}$ for OCCAM and $70 \mathrm{~Sv}$ for POCM_4C), adding weight to the statement of Stammer et al. (1996) that ocean models are known for overestimating the transport of the ACC by up to a factor of two. OCCAM also has larger mean transports than those derived from hydrographic data in the Pacific Ocean away from the ACC (Saunders et al., 1999). The models predict a significant barotropic component of transport across the A23 section (total barotropic transport $=86 \mathrm{~Sv}$ for OCCAM, $101 \mathrm{~Sv}$ for POCM_4C) and it would be useful for further model validation to repeat the analysis with hydrographic sections that have absolute velocity data available.

The velocities in the SACCF are not unrealistic in both OCCAM and POCM 4C; the SB jet is merged with the SACCF jet in OCCAM, as is often seen in observations, in POCM_4C the flow associated with the $\mathrm{SB}$ is slower than in the ocean. There are unsubstantiated strong jets in OCCAM south of the ACC, one of which appears to be associated with the anomalous Scotia Sea water mass and the other with the modelled WF. That the models resolve these fronts to any degree shows that there are frontogenetic processes in operation in the models since they were both initialised from smoothed climatological data in which the fronts are smeared out. One way that frontal jets can be accelerated is through eddy energy convergence. Given the resolution of the models, these processes will be weaker because eddying action is weaker in the models. Although both models are termed eddy-permitting, at the high latitudes studied here the grid resolution is close to the internal radius of deformation. There are other processes though in which fronts are formed (e.g. convergence of $f / h$ contours) and clearly, given that the fronts have similar geostrophic velocities to the A23 data, the processes in operation are at least adequate.

\section{Summary}

We have described a validation of two time-varying forced, high resolution ocean models by examining horizontal circulation fields from the models, sea surface height variability and the water mass properties and distribution. The two models fare better at reproducing different aspects of the Scotia Sea circulation and so they should be used in ways that utilise their strengths. Both models represent the regional water masses and simulate realistic velocities for the SACCF but overestimate transport generally. OCCAM simulates well the circulation around South Georgia, while POCM_4C better simulates the circulation of the central Scotia Sea. The surface waters in the models have some problems: they are too saline (by 0.12-0.40) in OCCAM and too warm (by $>2{ }^{\circ} \mathrm{C}$ ) in POCM_4C. WW, a remnant of the surface water, also has differences in the models compared with the ocean. WW relies on having a good seasonal cycle and depends on realistic surface fluxes. In OCCAM, WW is absent from the southern stations and in POCM_4C, the WW is so cold that it has temperatures lower than the local freezing point $\left(<-2{ }^{\circ} \mathrm{C}\right)$. OCCAM suffers from too little bottom water formation, coupled with excessive diapycnal mixing which mixes away the existing bottom water, causing disruption of the central Scotia Sea circulation. 
The bathymetry in POCM_4C needs to be corrected to ensure proper topographic steering of the regional circulation. However, despite all this, the fact that the models have been forced with timevarying fields affords a great chance to investigate variability in the study region that a lack of observational data precludes.

Although not the focus of this study, it should be noted that models of differing architecture can also lead to improved simulation of specific processes (Chassignet et al., 1996, 2000). However, there are several recommendations as a result of this study to improve the performance of $z$-level models in this region. Increasing the model resolution, both horizontally and vertically, so that the models are eddy-resolving at high latitudes should improve variability, sharpen the fronts and allow better representation of the bathymetry. Checking and correcting the model's bathymetry, including the depth of sills and channels as is already done in OCCAM, will mean that currents are correctly topographically steered. Using improved surface fluxes, checking the climatology where necessary, is vital for ensuring correct surface properties, particularly in winter as it is these values that are transmitted into the ocean interior. A sea-ice model is required to produce correct air-sea heat fluxes and hence prevent surface temperatures falling below the freezing point. Better bottom water formation processes, either through better representation of the processes themselves, or using subsurface forcing at boundaries as POCM_4C does, will allow further improvement to the model circulation. Finally, horizontal and vertical mixing have been identified throughout this study as potential contributors to some of the mismatches with the observed data. Future models should ensure that parameterisations lead to realistic levels of near-surface mixing. Elimination of spurious diapycnal mixing associated with the numerical advection scheme is crucial (Griffies et al., 2000; Lee et al., 2002). Horizontal dissipation schemes can produce significant levels of unwanted diapycnal mixing even in eddy-resolving ocean models (Roberts and Marshall, 1998). The use of adiabatic dissipation schemes can eradicate this problem (Roberts and Marshall, 1998; Smith and Gent, in press). Which of all of these changes is most important, or should be done first, depends on what is required from the model. For example, if the user is only interested in surface currents and not in deep water formation, then a solution would be to apply a better bathymetry and use subsurface restoration for the deeper waters. However, if the user wants to investigate water mass formation, then ensuring realistic surface fluxes should be paramount.

\section{Acknowledgements}

We thank Beverly de Cuevas and Andrew Coward for help extracting the OCCAM output and Robin Tokmakian for providing the POCM_4C output. We had useful discussions with David Webb and Andrew Coward about OCCAM, and with Robin Tokmakian about POCM_4C. Alberto Naveira Garabato kindly gave us permission to reproduce his current flows in Fig. 3. We thank Martin Price for calculating the altimetric sea surface height variability field. The altimeter products were produced by the CLS Space Oceanography Division as part of the Environment and Climate EC AGORA (ENV4-CT9560113) and DUACS (ENV4-CT96-0357) projects. Finally, we wish to thank two anonymous reviewers for their constructive comments and suggestions which have helped us to much improve the manuscript. This research was funded by a Natural Environment Research Council (NERC) CASE Ph.D. studentship between the 
University of East Anglia and the British Antarctic Survey. WOCE section A23 was funded by NERC WOCE grant GST/02/575.

\section{References}

Arhan, M., Naveira Garabato, A.C., Heywood, K.J., Stevens, D.P., 2002. The Antarctic Circumpolar Current between the Falkland Islands and South Georgia. J. Phys. Oceanogr. 32, 1914-1931.

AVISO, 1996. AVISO User Handbook: Merged TOPEX/POSEIDON Products. AVI-NT-02-101-CN, Edition 3.0, CNES, Toulouse.

AVISO, 1998. AVISO User Handbook: Sea Level Anomalies (SLAs). AVI-NT-011-312-CN, Edition 3.1, CNES, Toulouse.

Barnier, B., Siefridt, L., Marchesiello, P., 1995. Thermal forcing for a global ocean circulation model using a 3-year climatology of ECMWF analyses. J. Mar. Syst. 6, 363-380.

Chassignet, E.P., Arango, H., Dietrich, D., Ezer, T., Ghil, M., Haidvogel, D.B., Ma, C.-C., Mehra, A., Paiva, A.M., Sirkes, Z., 2000. DAMÉE-NAB: the base experiments. Dyn. Atmos. Oceans 32, 155-183.

Chassignet, E.P., Smith, L.T., Bleck, R., Bryan, F.O., 1996. A model comparison: Numerical simulations of the North and Equatorial Atlantic oceanic circulation in depth and isopycnic coordinates. J. Phys. Oceanogr. 26, 1849-1867.

Croxall, J.P., 1987. The status and conservation of Antarctic seals and seabirds-A review. Environ. Int. 13, 55-70.

de Cuevas, B.A, Webb, D.J., 1999. AGORA Final Report. Technical report, Southampton Oceanography Centre, Southampton, UK.

Gerdes, R., 1993. A primitive equation ocean circulation model using a general vertical coordinate transformation. Part II: Application to an overflow problem. J. Geophys. Res. 98, 14702-14726.

Gordon, A.L., Georgi, D.T., Taylor, H.W., 1977. Antarctic Polar Frontal Zone in the Western Scotia Sea-Summer 1975. J. Phys. Oceanogr. 7 (3), 309-328.

Gordon, A.L., Molinelli, E., Baker, T., 1978. Large-scale relative dynamic topography of the Southern Ocean. J. Geophys. Res. 83 (C6), 3023-3032.

Griffies, S.M., Pacanowski, R.C., Hallberg, R.W., 2000. Spurious diapycnal mixing associated with advection in a $z$ coordinate ocean model. Mon. Weather Rev. 128, 538-564.

Grose, T.J., Johnson, J.A., Bigg, G.R., 1995. A comparison between the FRAM (Fine Resolution Antarctic Model) results and observations in the Drake Passage. Deep-Sea Res. I 42 (3), 365-388.

Hellerman, S., Rosenstein, M., 1983. Normal monthly wind stress over the world ocean with error estimates. J. Phys. Oceanogr. 13, 1093-1104.

Heywood, K.J., King, B.A., 2002. Water masses and baroclinic transports in the South Atlantic and Southern oceans. J. Mar. Res. 60, 639-676.

Heywood, K.J., Naveira Garabato, A.C., Stevens, D.P., Muench, R.D., in press. On the fate of the Antarctic Slope Front and the origin of the Weddell Front. J. Geophys. Res.

Jayne, S.R., Tokmakian, R., 1997. Forcing and sampling of ocean general circulation models: Impact of high-frequency motions. J. Phys. Oceanogr. 27 (6), 1173-1176.

Killworth, P.D., Stainforth, D., Webb, D.J., Paterson, S.M., 1991. The development of a free surface Bryan-CoxSemtner ocean model. J. Phys. Oceanogr. 21, 1333-1348.

Large, W.G., McWilliams, J.C., Doney, S.C., 1994. Oceanic vertical mixing: a review and a model with a nonlocal boundary layer parameterization. Rev. Geophys. 32, 363-403.

Le Traon, P.Y., Nadal, F., Ducet, N., 1998. An improved mapping method of multi-satellite altimeter data. J. Atmos. Oceanic Tech. 16, 522-534.

Lee, M.-M., Coward, A.C., Nurser, A.J.G., 2002. Spurious diapycnal mixing of the deep waters in an eddy-permitting global ocean model. J. Phys. Oceanogr. 32 (5), 1522-1535.

Levitus, S., 1982. Climatological atlas of the world ocean. Technical Report 13, NOAA, Rockville, MD.

Levitus, S., Boyer, T., 1994. World Ocean Atlas 1994 Volume 4: Temperature. NOAA Atlas NESDIS 4, US Department of Commerce, Washington, DC. 
Levitus, S., Boyer, T.P., Conkwright, M.E., O’Brien, T., Antonov, J., Stephens, C., Stathoplos, L., Johnson, D., Gelfeld, R., 1998. World Ocean Database 1998: Volume 1: Introduction. NOAA Atlas NESDIS 18, US Gov. Printing Off., Washington, DC.

Levitus, S., Burgett, R., Boyer, T., 1994. World Ocean Atlas 1994 Volume 3: Nutrients. NOAA Atlas NESDIS 3, US Department of Commerce, Washington, DC.

Locarnini, R.A., Whitworth, T., Nowlin, W.D., 1993. The importance of the Scotia Sea on the outflow of Weddell Sea Deep Water. J. Mar. Res. 51, 135-153.

Maltrud, M.E., McClean, J.L., in press. An eddy resolving global $1 / 10^{\circ}$ ocean simulation. Ocean Modell.

McClean, J.L., Semtner, A.J., Zlotnicki, V., 1997. Comparisons of mesoscale variability in the Semtner-Chervin $1 / 4^{\circ}$ model, the Los Alamos Parallel Ocean Program 1/6 $6^{\circ}$ model, and TOPEX/POSEIDON data. J. Geophys. Res. 102 (C11), 25203-25226.

Meredith, M.P., Naveira Garabato, A.C., Stevens, D.P., Heywood, K.J., Sanders, R.J., 2001. Deep and bottom waters in the eastern Scotia Sea: Rapid changes in properties and circulation. J. Phys. Oceanogr. 31, 2157-2168.

Moore, J.K., Abbott, M.R., Richman, J.G., 1997. Variability in the location of the Antarctic Polar Front $\left(90^{\circ}-20^{\circ} \mathrm{W}\right)$ from satellite sea surface temperature data. J. Geophys. Res. 102 (C13), 27825-27833.

Murphy, E.J., Watkins, J.L., Reid, K., Trathan, P.N., Everson, I., Croxall, J.P., Priddle, J., Brandon, M.A., Brierley, A.S., Hofmann, E., 1998. Interannual variability of the South Georgia marine ecosystem: biological and physical sources of variation in the abundance of krill. Fish. Oceanogr. 7 (3/4), 381-390.

Naveira Garabato, A.C., Heywood, K.J., Stevens, D.P., 2002. Modification and pathways of Southern Ocean deep waters in the Scotia Sea. Deep-Sea Res. I 49, 681-705.

Olbers, D., Gouretski, V., Seiß, G., Schröter, J., 1992. Hydrographic Atlas of the Southern Ocean. Technical report, Alfred Wegener Institute, Bremerhaven.

Orsi, A.H., Whitworth, T., Nowlin, W.D., 1995. On the meridional extent and fronts of the Antarctic Circumpolar Current. Deep-Sea Res. 42 (5), 641-673.

Pacanowski, R.C., Philander, S.G.H., 1981. Parameterization of vertical mixing in numerical models of tropical oceans. J. Phys. Oceanogr. 11, 1443-1451.

Rintoul, S.R., Bullister, J.L., 1999. A late winter hydrographic section from Tasmania to Antarctica. Deep-Sea Res. I 46 (8), 1417-1454.

Roberts, M., Marshall, D., 1998. Do we require adiabatic dissipation schemes in eddyre-solving ocean models? J. Phys. Oceanogr. 28, 2050-2063.

Roberts, M.J., Marsh, R., New, A.L., Wood, R.A., 1996. An intercomparison of a Bryan-Cox type ocean model and an isopycnic ocean model. Part I: The subpolar gyre and high-latitude processes. J. Phys. Oceanogr. 26, 14951527.

Saunders, P.M., Coward, A.C., de Cuevas, B.A., 1999. Circulation of the Pacific Ocean seen in a global ocean model: Ocean Circulation and Climate Advanced Modelling project OCCAM. J. Geophys. Res. 104 (C8), 18281-18299.

Semtner, A.J., Chervin, R.M., 1992. Ocean general circulation from a global eddyresolving model. J. Geophys. Res. 97 (C4), 5493-5550.

Siefridt, L., Barnier, B., 1993. Banque de Données AVISO Vent/flux: Climatologie des Analyses de Surface du CEPMMT. Report No. 911430 025, 43 pp.

Sievers, H.A., Nowlin, W.D., 1984. The stratification and water masses at Drake Passage. J. Geophys. Res. 89 (C6), 10489-10514.

Smith, R.D., Gent, P.R., in press. Anisotropic GM parameterization for ocean models. J. Phys. Oceanogr.

Smith, W.F., Sandwell, D.T., 1997. Global seafloor topography from satellite altimetry and ship depth soundings. Science 277, 1956-1962.

Stammer, D., Tokmakian, R., Semtner, A., Wunsch, C., 1996. How well does a 1/4 global circulation model simulate large-scale oceanic observations? J. Geophys. Res. 101 (C10), 25779-25811.

Thompson, S.R., 1995. Sills of the global ocean: A compilation. Ocean Modell. 109, 7-9 (unpublished manuscripts).

Thorpe, S.E., 2001. Variability of the southern Antarctic Circumpolar Current in the Scotia Sea and its implications for transport to South Georgia. Ph.D. thesis, Univ. East Anglia, Norwich, UK.

Thorpe, S.E., Heywood, K.J., Brandon, M.A., Stevens, D.P., 2002. Variability of the southern Antarctic Circumpolar Current front north of South Georgia. J. Mar. Sys. 37, 87-105. 
Timmermann, R., Beckmann, A., 2004. Parameterization of vertical mixing in the Weddell Sea. Ocean Modell. 6, 83100.

Tokmakian, R., 1998. A high resolution ocean model with variable forcing of wind, heat, and freshwater: initial evaluation. Int. WOCE Newsletter 32, 26-28.

Tokmakian, R., Challenor, P.G., 1999. On the joint estimation of model and satellite sea surface height anomaly errors. Ocean Modell. 1, 39-52.

Webb, D.J., de Cuevas, B.A., 2003. The region of large sea surface height variability in the Southeast Pacific Ocean. J. Phys. Oceanogr. 33, 1044-1056.

Webb, D.J., de Cuevas, B.A., Coward, A.C., 1998. The first main run of the OCCAM global ocean model. Internal Document 34, Southampton Oceanography Centre.

Whitworth, T., Nowlin, W.D., 1987. Water masses and currents of the Southern Ocean at the Greenwich Meridian. J. Geophys. Res. 92 (C6), 6462-6476.

Whitworth, T., Nowlin, W.D., Orsi, A.H., Locarnini, R.A., Smith, S.G., 1994. Weddell Sea Shelf Water in the Bransfield Strait and Weddell Scotia Confluence. Deep-Sea Res. 41 (4), 629-641. 